Article

\title{
A Series of Robust Copper-Based Triazolyl Isophthalate MOFs: Impact of Linker Functionalization on Gas Sorption and Catalytic Activity ${ }^{\dagger}$
}

\author{
Ulrike Junghans ${ }^{1}$, Merten Kobalz ${ }^{2}$, Oliver Erhart ${ }^{2}$, Hannes Preißler ${ }^{3}$, Jörg Lincke ${ }^{2}$, \\ Jens Möllmer ${ }^{3}$, Harald Krautscheid ${ }^{2}$ and Roger Gläser 1,3,* \\ 1 Institute of Chemical Technology, Universität Leipzig, Linnéstr. 3, 04103 Leipzig, Germany; \\ ulrike.junghans@uni-leipzig.de \\ 2 Institute of Inorganic Chemistry, Universität Leipzig, Johannisallee 29, 04103 Leipzig, Germany; \\ merten.kobalz@chemie.uni-leipzig.de (M.K.); O.Erhart@web.de (O.E.); joerglincke@gmx.de (J.L.); \\ krautscheid@rz.uni-leipzig.de (H.K.) \\ 3 Institut für Nichtklassische Chemie e.V., Permoserstr. 15, 04318 Leipzig, Germany; \\ preissler@inc.uni-leipzig.de (H.P.); moellmer@inc.uni-leipzig.de (J.M.) \\ * Correspondence: roger.glaeser@uni-leipzig.de; Tel.: +49-341-9736301 \\ + Dedicated to Prof. Dr. Dr. h.c. Lothar Beyer on the occasion of his 80th birthday.
}

Academic Editor: Changle Chen

Received: 3 February 2017; Accepted: 21 March 2017; Published: 24 March 2017

\begin{abstract}
The synthesis and characterization of an isomorphous series of copper-containing microporous metal-organic frameworks $(\mathrm{MOFs})$ based on triazolyl isophthalate linkers with the general formula ${ }_{\infty}^{3}\left[\mathrm{Cu}_{4}\left(\mu_{3}-\mathrm{OH}\right)_{2}\left(\mathrm{R}^{1}-\mathrm{R}^{2} \text {-trz-ia }\right)_{3}\left(\mathrm{H}_{2} \mathrm{O}\right)_{x}\right]$ are presented. Through size adjustment of the alkyl substituents $\mathrm{R}^{1}$ and/or $\mathrm{R}^{2}$ at the linker, the impact of linker functionalization on structure-property relationships was studied. Due to the arrangement of the substituents towards the cavities, the porosity (pore fraction $28 \%-39 \%$ ), as well as the pore size can be adjusted by the size of the substituents of the triazole ring. Thermal analysis and temperature-dependent PXRD studies reveal a thermal stability of the MOFs up to $230^{\circ} \mathrm{C}$ due to increasing framework stability through fine-tuning of the linker substitution pattern. Adsorption of $\mathrm{CO}_{2}(298 \mathrm{~K})$ shows a decreasing maximum loading with increasing steric demand of the substituents of the triazole ring. Furthermore, the selective oxidation of cyclohexene with tert-butyl hydroperoxide (TBHP) is studied over the MOFs at $323 \mathrm{~K}$ in liquid chloroform. The catalytic activity increases with the steric demand of the substituents. Additionally, these isomorphous MOFs exhibit considerable robustness under oxidizing conditions confirmed by $\mathrm{CO}_{2}$ adsorption studies, as well as by the catalytic selective oxidation experiments.
\end{abstract}

Keywords: triazolyl isophthalate MOFs; crystal structures; structure-property relationship; linker substitution pattern; cyclohexene oxidation; heterogeneous catalysis

\section{Introduction}

Since the 1990s, metal-organic frameworks (MOFs) have emerged as an attractive class of porous materials for a broad spectrum of applications, like gas storage [1-4] and separation [5-9], as well as sensor design [10], biomedicine [11] and heterogeneous catalysis [12-15]. This versatile applicability derives from their large specific surface area, tunable properties, as well as their structural and chemical diversity $[16,17]$. However, in contrast to conventional materials, such as zeolites, the major drawback of MOFs is their limited thermal, hydrothermal and chemical stability [12]. Hence, in recent years, increasing attention has been paid to systematic investigations on isostructural MOFs by linker 
functionalization [18-21], metal ion substitution [22] and post-synthetic modification [23-26]. Typically, these modified MOFs show improved material properties, such as higher selectivity in terms of gas separation $[27,28]$ or higher catalytic activity [29]. Furthermore, the hydrothermal stability of MOFs can be improved through linker functionalization with alkyl groups, resulting in an increased hydrophobic nature of the MOF surface $[13,30,31]$. Further, stability towards water, as well as oxidizing conditions is often required for the application of the MOFs as catalysts in the selective oxidation of organic substrates. For instance, several MOFs with nitrogen-containing aromatic moieties within the linker exhibit considerable robustness under these conditions [32,33].

Among the MOF-based catalysts for selective oxidations, those containing copper as the active element bear particular potential. Thus, the well-known $\mathrm{Cu}_{3}(\mathrm{BTC})_{2}$ (BTC: 1,3,5-benzenetricarboxylate; also known as HKUST-1, HKUST: Hong Kong University of Science and Technology) was extensively studied, e.g., in the oxidation of xanthene [34], benzylic alcohols [35] or cyclooctene [36]. The "Cu-MOFs" [Cu(bpy)( $\left.\left.\mathrm{H}_{2} \mathrm{O}\right)(\mathrm{bpy})\left(\mathrm{BF}_{4}\right)_{2}\right]$ [37], [ $\left.\mathrm{Cu}_{2}(\mathrm{bipy})_{2}(\mathrm{btec})\right]$ [38], [Cu(bipy) $\left(\mathrm{H}_{2}\right.$ btec) $]$ [39,40], phenoxyacetic acid derivatives $\left[\mathrm{Cu}\left(\mathrm{L}_{1}\right)_{2}\left(\mathrm{H}_{2} \mathrm{O}\right)_{2}\right],\left[\mathrm{Cu}\left(\mathrm{L}_{1}\right)_{2}\left(\mathrm{H}_{2} \mathrm{O}\right)(\mathrm{Py})_{2}\right]$, $\left[\mathrm{Cu}\left(\mathrm{L}_{3}\right)\left(\mathrm{H}_{2} \mathrm{O}\right) \mathrm{Cl}\right]$ [41], [Cu $\left(\mathrm{Cu}_{2}(\mathrm{OH})(\mathrm{BTC})\left(\mathrm{H}_{2} \mathrm{O}\right)\right]_{n} \cdot 2 n \mathrm{H}_{2} \mathrm{O}$ [42], $\left\{\left[\mathrm{Cu}_{3} \mathrm{Ln}_{2}-(\text { oda })_{6}\left(\mathrm{H}_{2} \mathrm{O}\right)_{6}\right] \cdot n \mathrm{H}_{2} \mathrm{O}\right\}_{n}$ [43] and $\left\{\left[\mathrm{Cu}_{0.5} \mathrm{La}_{2}(\mathrm{HPDC})(\mathrm{PDC})_{2}-\left(\mathrm{SO}_{4}\right)\left(\mathrm{H}_{2} \mathrm{O}\right)_{2}\right] \mathrm{H}_{2} \mathrm{O}\right\}_{n}$ [44] also show catalytic activity for the selective oxidation of linear or cyclic alkenes with molecular oxygen or tert-butyl hydroperoxide (TBHP).

However, systematic studies on the adsorption and catalytic properties of MOFs by only one type of functionalization in the organic linker are still rare. The present work was, thus, devoted to the synthesis and investigation of the crystal structure, the thermal and adsorptive properties, as well as the catalytic activity of a series of copper-containing isomorphous MOFs based on triazolyl isophthalate linkers [45-49] with the general formula ${ }_{\infty}^{3}\left[\mathrm{Cu}_{4}\left(\mu_{3}-\mathrm{OH}\right)_{2}\left(\mathrm{R}^{1}-\mathrm{R}^{2}-\operatorname{trz}-\mathrm{ia}\right)_{3}\left(\mathrm{H}_{2} \mathrm{O}\right)_{x}\right]$. The ligands differ in their steric demand of the triazole substituents $R^{1}$ and $R^{2}$, i.e., $R=H$, Me, Et. This allows a comprehensive investigation of the impact of gradual changes in the linker on the MOF structure and porosity, as well as on gas adsorption, thermal and catalytic properties. The influence of different functional groups within the triazolyl isophthalate linker on the gas sorption properties was already observed recently with a related series of MOFs based on the paddle wheel motif [48]. In addition, triazole-based MOFs were shown to be active catalysts in the selective oxidation of cyclooctene and cyclohexene with TBHP $[36,50,51]$. Accordingly, the selective oxidation of cyclohexene with TBHP in the liquid phase was chosen as a test reaction in the present work to investigate the influence of the triazole substituents on the catalytic activity of the MOFs. In addition, this conversion is a widely-studied test reaction to investigate the catalytic activity of newly-developed oxidation catalysts, since the formation of the oxidation products strongly depends on the chosen reaction conditions, as well as the used catalyst [52-54]. Thus, a direct comparison of the obtained results to already published ones is possible. Lastly, the catalytic activity, selectivity and stability of ${ }_{\infty}^{3}\left[\mathrm{Cu}_{4}\left(\mu_{3}-\mathrm{OH}\right)_{2}\left(\mathrm{R}^{1}-\mathrm{R}^{2} \text {-trz-ia) }\right)_{3}\left(\mathrm{H}_{2} \mathrm{O}\right)_{x}\right]$ catalysts is directly compared to that of the reference materials $\mathrm{Cu}_{3}(\mathrm{BTC})_{2}$ and $\mathrm{Cu}\left(\mathrm{NO}_{3}\right)_{2}$.

\section{Results and Discussion}

\subsection{Synthesis and X-ray Crystallography of $\mathbf{1 - 5}$}

Based on five triazolyl isophthalate ligands [47,48] with methyl and ethyl substituents, including mono- and di-substituted linkers, fine-tuning of the steric demand of the ${ }_{\infty}^{3}\left[\mathrm{Cu}_{4}\left(\mu_{3}-\mathrm{OH}\right)_{2}\right.$ $\left.\left(\mathrm{R}^{1}-\mathrm{R}^{2}-\text { trz-ia }\right)_{3}\left(\mathrm{H}_{2} \mathrm{O}\right)_{\mathrm{x}}\right]$ MOFs $(\mathbf{1}-\mathbf{5})$ is possible (Table 1$)$. The crystal structures of $\mathbf{3}-\mathbf{5}$ were determined by single crystal $\mathrm{X}$-ray diffraction. Suitable crystals were obtained starting from the protonated ligands and $\mathrm{Cu}(\mathrm{OAc})_{2}$ or $\mathrm{CuSO}_{4}$ via solvothermal synthesis using $\mathrm{H}_{2} \mathrm{O}, \mathrm{H}_{2} \mathrm{O} / \mathrm{MeCN}$ or $\mathrm{H}_{2} \mathrm{O} / \mathrm{MeOH}$ as solvents. In addition, compounds $\mathbf{1 - 5}$ are easily accessible in the gram scale by refluxing a solution of the starting materials in $\mathrm{H}_{2} \mathrm{O} / \mathrm{MeOH}$, in the case of 4 even in the "green" solvent $\mathrm{H}_{2} \mathrm{O}$. 3-5 crystallize in the orthorhombic space group Pbca (No. 61) with eight formula units (Z) per unit cell (Table 2). According to the X-ray powder diffraction (PXRD) patterns, $\mathbf{1}$ and $\mathbf{2}$ complete the series of isomorphous 
MOFs 1-5, but are not accessible as single crystals. Detailed MOF synthesis protocols and crystal structure data are reported in the Electronic Supporting Information (ESI, Tables S1 and S2).

Table 1. Linkers with different substitution patterns in 1-5.

\begin{tabular}{|c|c|c|c|c|}
\hline MOF & Ligand & $\mathrm{R}^{1}$ & $\mathbf{R}^{2}$ & $\Theta_{0}$ \\
\hline 1 & $(\text { H-Me-trz-ia })^{2-}$ & $\mathrm{H}$ & $\mathrm{Me}$ & \\
\hline 2 & $(\text { H-Et-trz-ia })^{2-}$ & $\mathrm{H}$ & Et & \\
\hline 3 & $\left(\mathrm{Me}_{2}-\operatorname{trz}-\mathrm{ia}\right)^{2-}$ & $\mathrm{Me}$ & $\mathrm{Me}$ & \\
\hline 4 & $(\text { Me-Et-trz-ia })^{2-}$ & $\mathrm{Me}$ & Et & \\
\hline 5 & $\left(\mathrm{Et}_{2}-\mathrm{trz}-\mathrm{ia}\right)^{2-}$ & Et & Et & $\mathrm{N}-\mathrm{N}$ \\
\hline
\end{tabular}

Table 2. Space group, unit cell parameters (a, b, c), volume (V) and formula units (Z) per unit cell of 3-5.

\begin{tabular}{cccc}
\hline MOF & $\begin{array}{c}\mathbf{3} \\
\left(\mathrm{R}^{1}=\mathrm{R}^{2}=\mathrm{Me}\right)\end{array}$ & $\begin{array}{c}\mathbf{4} \\
\left(\mathrm{R}^{1}=\mathrm{Me}, \mathrm{R}^{2}=\mathrm{Et}\right)\end{array}$ & $\begin{array}{c}\mathbf{5} \\
\left(\mathrm{R}^{1}=\mathrm{R}^{2}=\mathrm{Et}\right)\end{array}$ \\
\hline space group & Pbca $($ No. 61) & Pbca (No. 61) & Pbca (No. 61) \\
\hline $\mathrm{a} / \mathrm{pm}$ & $1875.00(8)$ & $1872.71(3)$ & $1854.69(5)$ \\
$\mathrm{b} / \mathrm{pm}$ & $2428.78(6)$ & $2461.21(5)$ & $2420.12(7)$ \\
$\mathrm{c} / \mathrm{pm}$ & $2540.75(7)$ & $2525.07(6)$ & $2547.32(7)$ \\
$\mathrm{V} / 10^{6} \mathrm{pm}^{3}$ & $11,570.6(7)$ & $11,638.4(4)$ & $11,433.8(6)$ \\
$\mathrm{Z}$ & 8 & 8 & 8 \\
\hline
\end{tabular}

The asymmetric unit of 3-5 contains three linker molecules, one $\left[\mathrm{Cu}_{4}\left(\mu_{3}-\mathrm{OH}\right)_{2}\right]^{6+}$ unit and one $(3,5)$ or two $(4)$ coordinating water molecules. The secondary building unit (SBU) is formed by four $\mathrm{Cu}^{2+}$ ions and two triple bridging hydroxide ions (Figure 1). Additionally, the $\mathrm{Cu}^{2+}$ ions are bridged by three triazole groups and one carboxylate group (O11e, O12e). The four $\mathrm{Cu}^{2+}$ ions in the crystal structures of $\mathbf{3}$ and $\mathbf{5}$ show a distorted square pyramidal coordination sphere. Due to coordination of a second water molecule in the case of 4 , the $\mathrm{Cu}^{2+}$ ion $\mathrm{Cu} 4$ shows a distorted octahedral coordination environment (cf. (confer) Figure 1). All of these polyhedra are elongated, as expected for the $\mathrm{d}^{9}$ electron configuration according to the JAHN-TELLER theorem. This is illustrated by the significantly longer bonds in apical positions compared to bond lengths in equatorial positions (Table 3). The open metal sites of the $\mathrm{Cu}^{2+}$ ions are shielded by triazole substituents and the steric demand of the carboxylate groups. As shown in Figure 1, hydrogen bonds are built up by coordinating water molecules, bridging hydroxide ions and carboxylate groups.

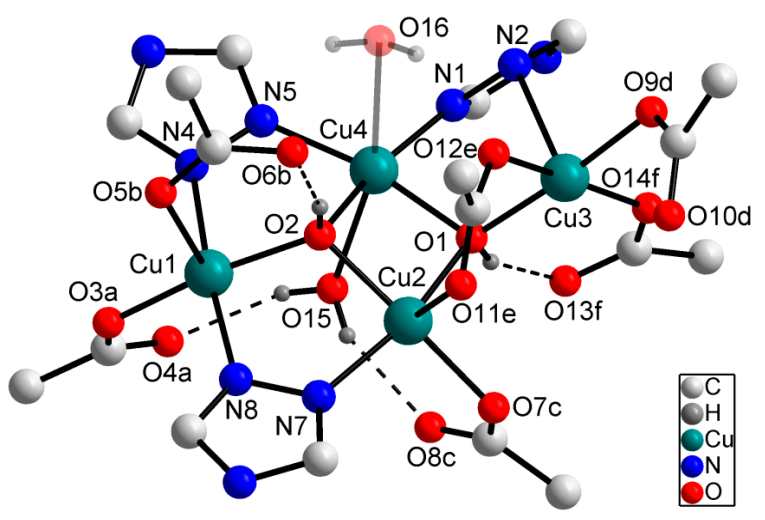

Figure 1. Structural motif of 3-5: Coordination environment of the $\mathrm{Cu}^{2+}$ ions. The substituents of the triazole rings are omitted for clarity. The coordinating water molecule $\mathrm{O} 16$ is present only in the crystal structure of 4 . Symmetry codes: a: $x, 1.5-\mathrm{y},-0.5+\mathrm{z} ; \mathrm{b}:-0.5+\mathrm{x}, \mathrm{y}, 1.5-\mathrm{z}$; $: 1.5-\mathrm{x},-0.5+\mathrm{y}, \mathrm{z}$; d: $1-\mathrm{x}, 1-\mathrm{y}, 1-\mathrm{z} ; \mathrm{f}: 1.5-\mathrm{x}, 1-\mathrm{y}, 0.5+\mathrm{z}$. 
Table 3. Selected distances and angles in the crystal structures of 3-5.

\begin{tabular}{|c|c|c|c|c|c|c|c|}
\hline MOF & 3 & 4 & 5 & MOF & 3 & 4 & 5 \\
\hline \multicolumn{5}{|c|}{ bond length/pm } & \multicolumn{3}{|c|}{ angle ${ }^{\circ}$} \\
\hline $\mathrm{Cu} 1-\mathrm{O} 2$ & 193.2(4) & 192.3(2) & 192.7(2) & Cu3-O1 & 196.8(3) & 194.7(3) & $195.5(2)$ \\
\hline Cu1-N4 & 202.1(4) & $202.0(3)$ & 201.5(2) & Cu3-O12e & $195.6(4)$ & 195.8(3) & 195.1(2) \\
\hline $\mathrm{Cu} 1-\mathrm{O} 3 \mathrm{a}$ & 194.1(4) & 192.7(3) & 194.7(2) & Cu3-O9d & $196.4(4)$ & 194.7(3) & 194.3(2) \\
\hline Cu1-N8 & 200.3(4) & 202.6(3) & $201.8(2)$ & Cu3-O14f & $197.5(4)$ & 196.1(3) & $196.6(2)$ \\
\hline $\mathrm{Cu} 1 \cdots \mathrm{O} 5 \mathrm{~b}$ & $243.2(4)$ & $256.6(4)$ & $240.2(3)$ & $\mathrm{Cu} 3 \cdots \mathrm{N} 2$ & $246.9(5)$ & 268.3(5) & $256.2(3)$ \\
\hline Cu2-O1 & 196.9(3) & 195.9(2) & 198.3(2) & Cu4-O1 & 197.6(3) & 197.0(3) & 198.0(2) \\
\hline $\mathrm{Cu} 2-\mathrm{O} 2$ & 198.0(3) & 197.1(3) & 196.2(2) & $\mathrm{Cu} 4-\mathrm{O} 2$ & $196.8(4)$ & 196.3(2) & 195.7(2) \\
\hline $\mathrm{Cu} 2-\mathrm{O} 7 \mathrm{c}$ & 195.0(4) & 197.4(3) & 195.1(2) & Cu4-N1 & $198.4(5)$ & 198.5(3) & 198.8(3) \\
\hline Cu2-N7 & 201.4(5) & 199.0(3) & 201.8(3) & Cu4-N5 & 203.6(4) & 201.0(3) & 202.5(2) \\
\hline \multirow[t]{2}{*}{$\mathrm{Cu} 2 \cdots \mathrm{O} 11 \mathrm{e}$} & $224.4(4)$ & 221.9(3) & 219.6(3) & $\mathrm{Cu} 4 \cdots \mathrm{O} 15$ & $230.0(4)$ & $243.0(4)$ & $225.4(3)$ \\
\hline & & & & $\mathrm{Cu} 4 \cdots \mathrm{O} 16$ & - & $266.0(5)$ & - \\
\hline $\mathrm{O} 2-\mathrm{Cu} 1 \cdots \mathrm{O} 5 \mathrm{~b}$ & $91.6(1)$ & $84.9(1)$ & $91.89(8)$ & $\mathrm{O} 1-\mathrm{Cu} 3 \cdots \mathrm{N} 2$ & $82.8(2)$ & $79.7(1)$ & $81.24(9)$ \\
\hline O2-Cu1-N4 & $87.5(2)$ & 88.1(1) & $86.77(9)$ & O1-Cu3-O14f & 95.7(2) & 95.1(1) & $96.01(9)$ \\
\hline $\mathrm{O} 2-\mathrm{Cu} 2 \cdots \mathrm{O} 11 \mathrm{e}$ & $97.3(1)$ & $99.0(1)$ & $98.08(8)$ & 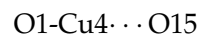 & $88.5(1)$ & $86.8(1)$ & $90.22(9)$ \\
\hline $\mathrm{O} 2-\mathrm{Cu} 2-\mathrm{O} 1$ & $80.7(1)$ & $81.2(1)$ & $81.08(8)$ & $\mathrm{O} 1-\mathrm{Cu} 4-\mathrm{O} 2$ & $80.8(1)$ & 81.1(1) & $81.28(8)$ \\
\hline
\end{tabular}

Each $\left[\mathrm{Cu}_{4}\left(\mu_{3}-\mathrm{OH}\right)_{2}\right]^{6+} \mathrm{SBU}$ is coordinated by nine triply bridging linker molecules (three triazole groups, six carboxylate groups). Topological analysis of the three-dimensional network reveals the point symbol $\left\{4.6^{2}\right\}_{2}\left\{4^{2} .6\right\}\left\{4^{7} \cdot 6^{22} \cdot 8^{7}\right\}$, which is not assigned to a known topology [55].

The pore fraction of 3-5 calculated from the crystal structure data is determined as $39 \%$ (3), $34 \%$ (4) and $28 \%$ (5), respectively [56]. As a representative example, the 3D packing in the crystal structure of 4 is shown in Figure 2. This packing diagram and also diagrams with other viewing directions (not shown) show that there are no straight pore channels in these crystal structures. Consequently, the pores are not easily visible by looking at these diagrams. More information can be gained from the calculations of pore size distributions (PSDs, Figure 2). The PSDs of 3-5 calculated on the basis of the crystal structure data show a multimodal shape with pore sizes in the range of $300-580 \mathrm{pm}$ (Figure 2) [57-59]. This confirms that pores are present within the investigated MOFs. Hence, 3-5 represent microporous materials. Due to the arrangement of the triazole substituents towards the cavities (Figure 2), the maximum pore size can be fine-tuned by the choice of the substituent. Therefore, targeted modification of the pore system is possible by adjusting the substitution pattern of the triazole ring.

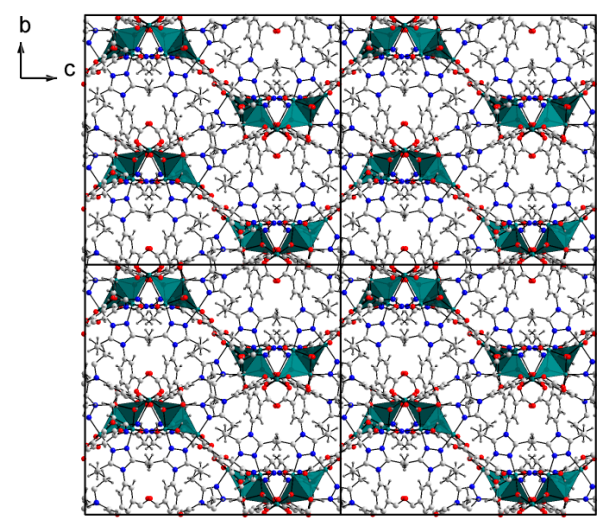

(a)

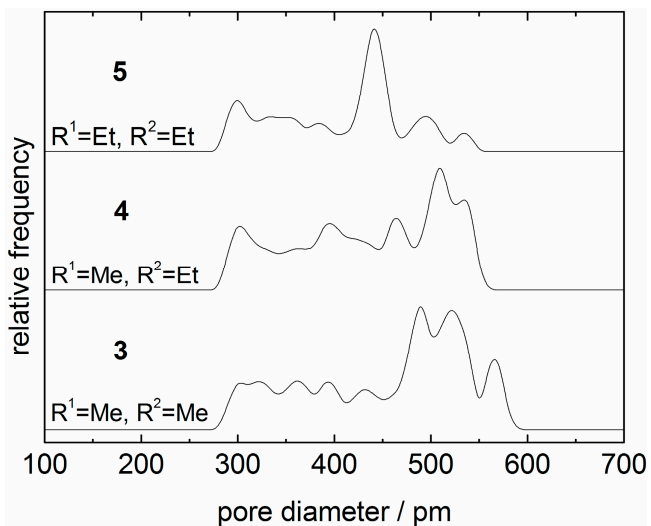

(b)

Figure 2. Arrangement of $\left[\mathrm{Cu}_{4}\left(\mu_{3}-\mathrm{OH}\right)_{2}\right]^{6+}$ units in the three-dimensional network of $4(2 \cdot 2 \cdot 2$ supercell, viewed along the crystallographic a-direction (a); and comparison of the calculated pore size distributions (PSDs, [57-59]) of 3-5 (b). 


\subsection{X-ray Powder Diffraction and Thermal Stability of 1-5}

As mentioned above, compounds $\mathbf{1}$ and $\mathbf{2}$ are not accessible as single crystals. Hence, single crystal X-ray analyses of these compounds could not be performed. However, as presented in Figure 3, Figures S1 and S4, the powder X-ray diffraction patterns of $\mathbf{1}$ and $\mathbf{2}$ closely resemble those of compounds 3-5. Based on these data, 1-5 can be regarded as isomorphous. Due to the overlap of the broadened reflections, indexing of the PXRD patterns of $\mathbf{1}$ and $\mathbf{2}$ was not possible. However, as the PXRD patterns of $\mathbf{1 - 5}$ are in good agreement except for minor deviations of intensity proportions of individual reflections (Figure 3), it can be concluded that both mono- and disubstituted triazolyl ligands are tolerated by the network.

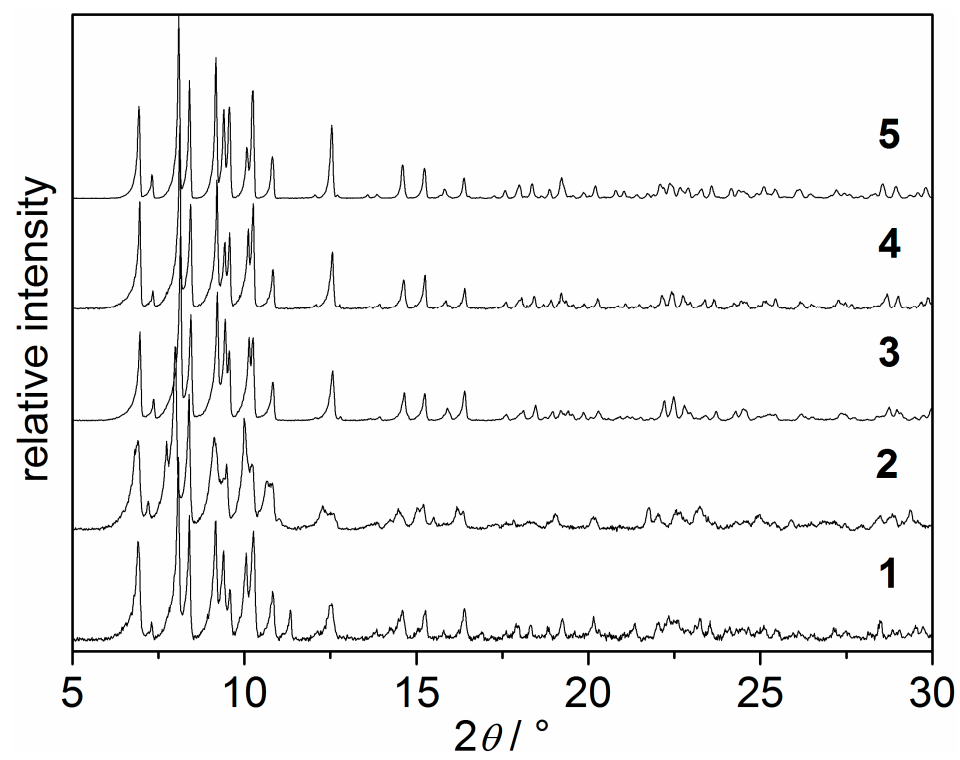

Figure 3. X-ray powder diffraction patterns $\left(\lambda\left(\mathrm{Cu}-\mathrm{K}_{\alpha 1}\right)=154.060 \mathrm{pm}\right)$ of $\mathbf{1}-\mathbf{5}$.

The PXRD patterns of $\mathbf{4}$ and $\mathbf{5}$ after various post-synthetic treatments (Soxhlet extraction with methanol, adsorption experiments, adsorption experiment and resolvation with methanol, catalytic test, catalytic test and resolvation with methanol, evacuation or after $16 \mathrm{~h}$ in boiling water) illustrate the robustness of these materials (Figure S2; comprehensive PXRD data of 1-3 are shown in Figure S1). As a representative example, 5 was chosen for the investigation of the stability of the framework materials towards hot liquid water, as this is a key requirement for the application of MOFs in adsorption processes and as heterogeneous catalysts. Although the synthesis of 5 requires the presence of methanol as the organic solvent, the PXRD pattern remains unchanged even after $16 \mathrm{~h}$ in boiling water. Further, the PXRD pattern of 4 shows no deviation from that of the pristine material pattern even in the evacuated state after activation under vacuum at $313 \mathrm{~K}$ for $24 \mathrm{~h}$. Due to this remarkable robustness, it can be concluded that 1-5 are rigid frameworks of the second generation according to the classification of Kitagawa et al. [16,60,61].

The thermal stability of the microporous framework materials 1-5 after Soxhlet extraction with methanol was studied by temperature-dependent X-ray powder diffraction (TD-PXRD) and simultaneous thermal analysis (TG-DTA-MS). The reflection positions of $\mathbf{1} \mathbf{2}$ and $\mathbf{5}$ remain unchanged with increasing temperature (Figure S4). In contrast, the TD-PXRD patterns of 3 and $\mathbf{4}$ show slight changes of individual reflection positions at elevated temperatures. However, a distinct phase change is not observed for 1-5, illustrating the robustness of the framework structures. The TD-PXRD patterns reveal a loss of crystallinity in the temperature range between $180^{\circ} \mathrm{C} \mathrm{(2)} \mathrm{and} 230{ }^{\circ} \mathrm{C}(5)$.

A comparative illustration of the TG-DTA-MS analyses of 1-5 after Soxhlet extraction with methanol is shown in Figure 4 (for individual diagrams and a more detailed description, see ESI 2.2 
and Figures S5-S7). All materials show a mass loss up to $200{ }^{\circ} \mathrm{C}$, which is related to the evaporation of guest molecules. Although all materials were Soxhlet extracted with methanol, the evaporation of water is still detected by MS at elevated temperatures. The multi-stepped water loss results from different degrees of adsorptive interaction with the walls of the pores of various sizes. The last peak in the MS signal of water $\left(m / z=18\left(\mathrm{H}_{2} \mathrm{O}\right)^{+}\right)$is assigned to the coordinated water molecules and bridging hydroxide ions. This water loss is accompanied by the thermal decomposition of the frameworks, associated with the release of $\mathrm{CO}_{2}$ from the organic linker.

The decomposition temperatures determined by TG-DTA-MS analysis are in good agreement with the values found by TD-PXRD (Figure S8). With increasing steric demand of the triazole substituents, a slight increase of the decomposition temperature from $1\left(22{ }^{\circ} \mathrm{C} ; \mathrm{R}^{1}=\mathrm{H}, \mathrm{R}^{2}=\mathrm{Me}\right)$ to $5\left(250{ }^{\circ} \mathrm{C} ; \mathrm{R}^{1}=\right.$ $\mathrm{R}^{2}=\mathrm{Et}$ ) is observed. This is most likely due to the reduced porosity and pore size and, thus, a reduced fragility of the framework.

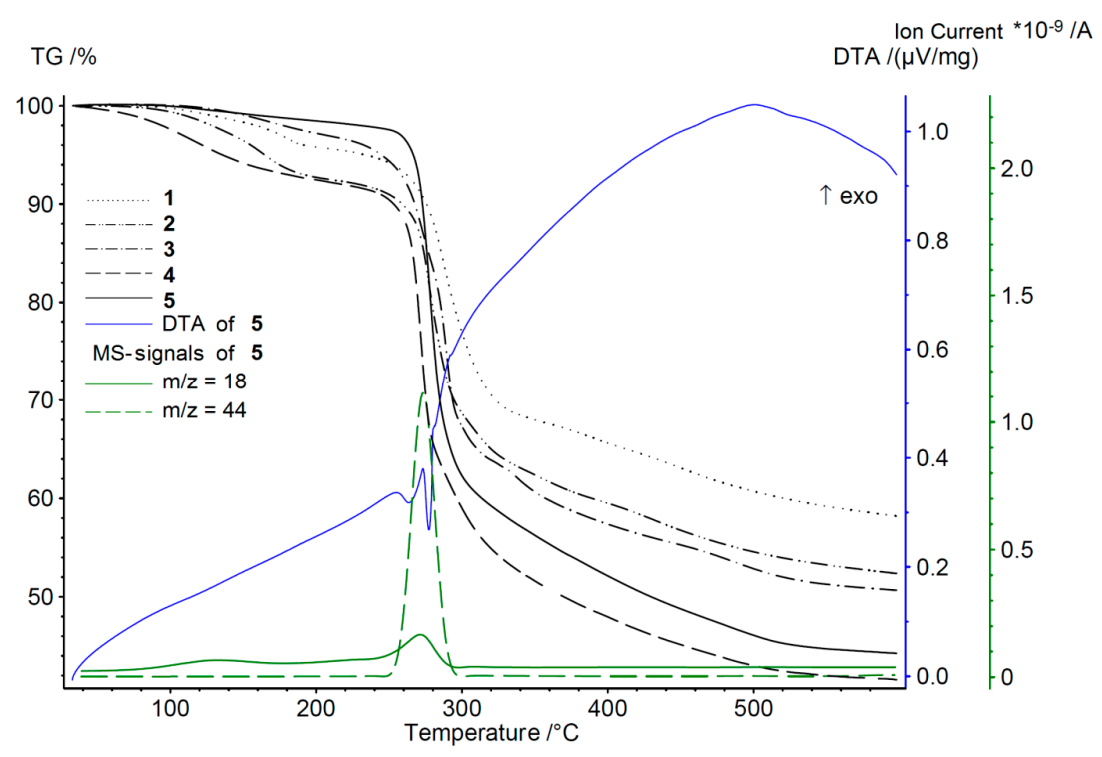

Figure 4. Simultaneous thermal analyses (TG-DTA-MS) of 1-5 after Soxhlet extraction with methanol. MS signals (5) of $\left(\mathrm{H}_{2} \mathrm{O}\right)^{+}(\mathrm{m} / z=18)$ and $\left(\mathrm{CO}_{2}\right)^{+}(\mathrm{m} / z=44)$ illustrate the evaporation of guest molecules and the decomposition of the framework, respectively.

\subsection{Adsorption of $\mathrm{CO}_{2}$}

In order to evaluate the adsorption characteristics of 1-5, high-pressure $\mathrm{CO}_{2}(298 \mathrm{~K})$ and low-pressure $\mathrm{N}_{2}(77 \mathrm{~K})$ adsorption studies were performed. The $\mathrm{CO}_{2}$ adsorption isotherms of 1-5 correspond to type I of the IUPAC classification of physisorption isotherms (Figure 5 and Figure S9) $[62,63]$. Obviously, the choice of the substituent clearly influences the saturation loading of $\mathrm{CO}_{2}$. However, the expected decrease of the maximum loading with increasing steric demand of the substituent on the triazole ring is not apparent at first sight. By detailed analysis of the pore volumes, this deviation can be explained.

As expected, the experimentally determined specific pore volume of $\mathbf{1}\left(\mathrm{R}^{1}=\mathrm{H}, \mathrm{R}^{2}=\mathrm{Me}\right.$, $\left.0.33 \mathrm{~cm}^{3} \mathrm{~g}^{-1}\right)$ is slightly larger compared to the calculated value of $3\left(\mathrm{R}^{1}=\mathrm{R}^{2}=\mathrm{Me}, 0.31 \mathrm{~cm}^{3} \mathrm{~g}^{-1}\right)$. Based on the specific pore volumes of 3-5 calculated from the crystal structure data, an increment of approximately $0.05 \mathrm{~cm}^{3} \mathrm{~g}^{-1}$ for a $\mathrm{CH}_{2}$ extension of the alkyl substituent is estimated (Table 4). Thus, the calculated pore volume of $\mathbf{1}$ is estimated to be approximately $0.36 \mathrm{~cm}^{3} \mathrm{~g}^{-1}$, which is somewhat larger compared to the experimental value. The experimentally determined specific pore volume of 2 $\left(0.22 \mathrm{~cm}^{3} \mathrm{~g}^{-1}\right)$ is significantly smaller compared to that of $\mathbf{1}$ and even smaller than the value found for 4 $\left(\mathrm{R}^{1}=\mathrm{Me}, \mathrm{R}^{2}=\mathrm{Et}, 0.26 \mathrm{~cm}^{3} \mathrm{~g}^{-1}\right)$. It is, however, in quite good agreement with the specific pore volume of $5\left(\mathrm{R}^{1}=\mathrm{R}^{2}=\mathrm{Et}\right)$. This finding gives rise to the assumption that the ethyl group in the structure of 2 is 
located towards the cavities and causes partial blocking of the pore system. Introduction of a second ethyl group (5) causes no significant pore volume reduction. This is in good agreement with the pore size distributions calculated based on single crystal structure data (Figure 2). $\mathrm{A} \mathrm{CH}_{2}$ extension of the methyl group (from 3 to 4 ) leads to a reduction of the maximum pore size. In contrast, the extension of the second methyl group (from 4 to 5 ) does not cause an additional contraction of the pore. In the case of 4 , the calculated pore volume is confirmed experimentally $\left(0.26 \mathrm{~cm}^{3} \mathrm{~g}^{-1}\right)$, while for 5 , a slightly smaller value is found (Table 4).

A peculiarity is found for 3. The experimentally-determined specific pore volume of this material $\left(0.36 \mathrm{~cm}^{3} \mathrm{~g}^{-1}\right)$ is significantly larger than the calculated value based on crystal structure data $\left(0.31 \mathrm{~cm}^{3} \mathrm{~g}^{-1}\right)$. A possible explanation for this result is a desolvated phase with a larger pore fraction compared to the structure of the as-synthesized material. However, a structural change during $\mathrm{CO}_{2}$ adsorption is unlikely, as this process would cause a stepwise uptake.

For the isomorphous MOF series 1-5, the $\mathrm{CO}_{2}$ adsorption capacity can be modified by fine-tuning of the substitution pattern of the triazole ring. The expected decrease of the maximum loading with increasing steric demand of the substituent is experimentally confirmed for $\mathbf{1}\left(\mathrm{R}^{1}=H, \mathrm{R}^{2}=\mathrm{Me}\right)$, $4\left(\mathrm{R}^{1}=\mathrm{Me}, \mathrm{R}^{2}=\mathrm{Et}\right)$ and $5\left(\mathrm{R}^{1}=\mathrm{R}^{2}=\mathrm{Et}\right)$. The low pressure $\mathrm{N}_{2}$ adsorption isotherms $(77 \mathrm{~K})$ correspond to type I of the IUPAC recommendations, as well. They show a steep increase of adsorbed volume followed by a pronounced plateau (Figure S10). However, in contrast to $\mathrm{CO}_{2}, \mathrm{~N}_{2}$ is not a proper probe molecule to experimentally prove the different specific pore volumes of 1-5.

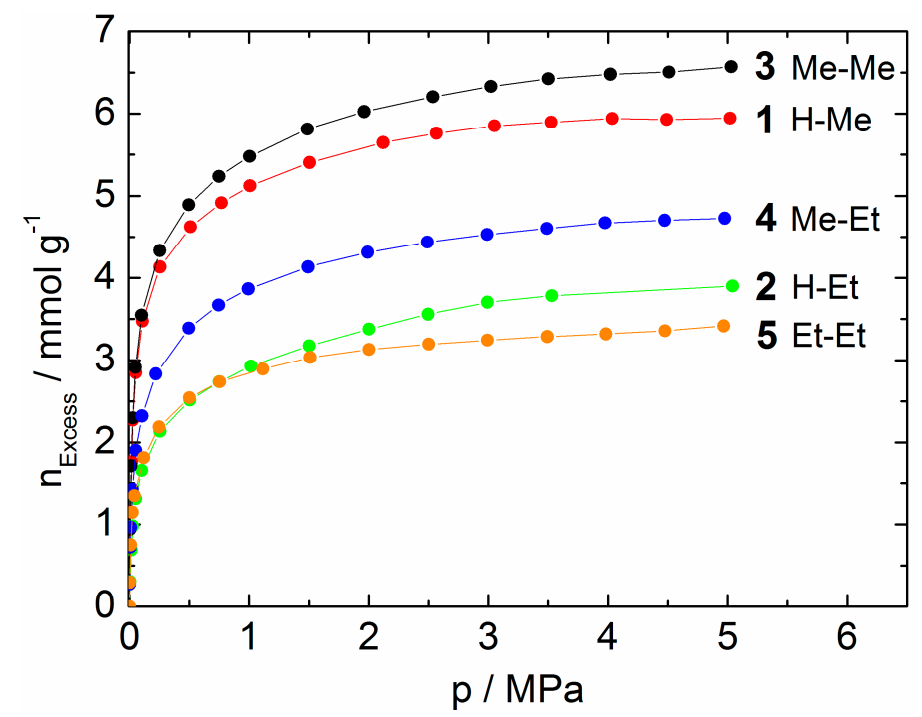

Figure 5. $\mathrm{CO}_{2}$ adsorption isotherms (298 K) of 1-5 (lines are to guide the eyes).

Table 4. Calculated (cal.) and experimentally determined specific pore volumes of 1-5 (GURVICH equation, saturation vapor pressure $\left.\mathrm{p}_{0}\left(\mathrm{CO}_{2}\right)=6.4121 \mathrm{MPa}, \mathrm{p}_{0}\left(\mathrm{~N}_{2}\right)=97.152 \mathrm{kPa}\right)[64,65]$.

\begin{tabular}{ccccccc}
\hline MOF & $\begin{array}{c}\text { Pore Fraction/\% } \\
{[\mathbf{5 6}]}\end{array}$ & $\rho / \mathbf{g ~ c m}^{-\mathbf{3}}$ & $\begin{array}{c}\mathrm{V}_{\text {pore }}(\mathrm{cal} .) / \\
\mathbf{c m}^{\mathbf{3}} \mathbf{g}^{-\mathbf{1}}\end{array}$ & $\begin{array}{c}\mathrm{V}_{\text {pore }}\left(\mathrm{CO}_{\mathbf{2}}\right) / \\
\mathbf{c m}^{\mathbf{3}} \mathbf{g}^{-\mathbf{1}}\end{array}$ & $\begin{array}{c}\mathrm{V}_{\text {pore }}\left(\mathrm{N}_{\mathbf{2}}\right) / \\
\mathbf{c m}^{\mathbf{3}} \mathbf{g}^{\mathbf{- 1}}\end{array}$ & $\begin{array}{c}\mathrm{S}_{\mathrm{BET}} / \\
\mathbf{m}^{\mathbf{2}} \mathbf{g}^{-\mathbf{1}}\end{array}$ \\
\hline $\mathbf{1}$ & $-\mathrm{a}$ & $-\mathrm{a}$ & $-{ }^{\mathrm{a}}$ & 0.33 & 0.26 & 580 \\
$\mathbf{2}$ & $-\mathrm{a}$ & $-\mathrm{a}$ & $-\mathrm{a}$ & 0.22 & 0.16 & 345 \\
$\mathbf{3}$ & 39 & 1.244 & 0.31 & 0.36 & 0.26 & 648 \\
$\mathbf{4}$ & 34 & 1.306 & 0.26 & 0.26 & 0.25 & 680 \\
$\mathbf{5}$ & 28 & 1.357 & 0.21 & 0.19 & 0.14 & 319 \\
\hline
\end{tabular}

${ }^{a}$ No value due to unavailable single crystal structure data. 


\subsection{Catalytic Selective Oxidation of Cyclohexene with TBHP over 1-5}

The MOFs 1-5 were studied as catalysts for the conversion of cyclohexene (Cyhex) with TBHP in liquid chloroform (Figure 6). As an example, Figure 7 shows the conversion of Cyhex and TBHP, as well as the selectivity for the corresponding reaction products over $\mathbf{5}$ in dependence of the reaction time. After $7 \mathrm{~h}, 56 \%$ Cyhex and 53\% TBHP are converted. Concomitantly, the selectivity for Cyhex-TBP decreases from $85 \%$ after $3 \mathrm{~h}$ of reaction to $77 \%$ after $7 \mathrm{~h}$ suggesting further conversion to 2-cyclohexen-1-one, the selectivity of which reaches $10 \%$. Other byproducts, cyclohexene oxide and 2-cyclohexen-1-ol, are formed in negligible amounts only (selectivity of $1 \%$ and $2 \%$, respectively). The observed product distribution suggests a similar reaction mechanism to that reported by Tonigold et al. [66], who investigated the selective cyclohexene oxidation under solvent-free conditions over the Co-containing MOF MFU-1 (MFU: Metal-organic framework Ulm University). They explained the formation of the reaction products via a radical-dominated reaction pathway involving the formation of tert-butoxyl and tert-butylperoxyl radicals at the metal sites of the MOF.

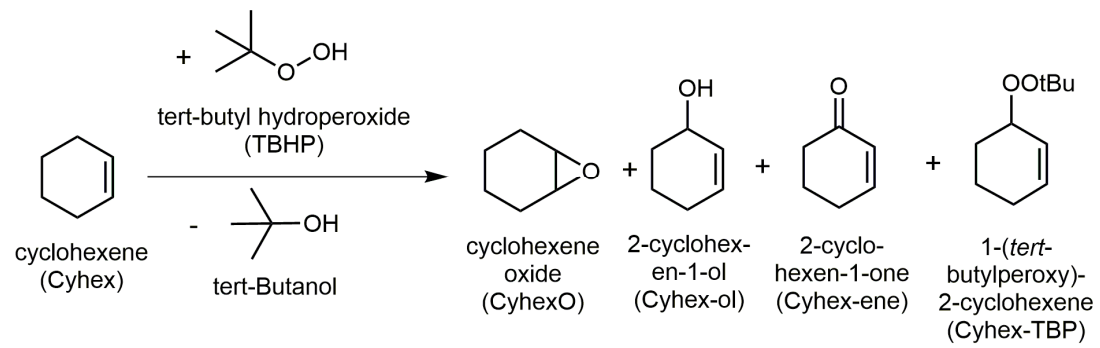

Figure 6. Reaction scheme of catalytic oxidation of cyclohexene with tert-butyl hydroperoxide (TBHP).

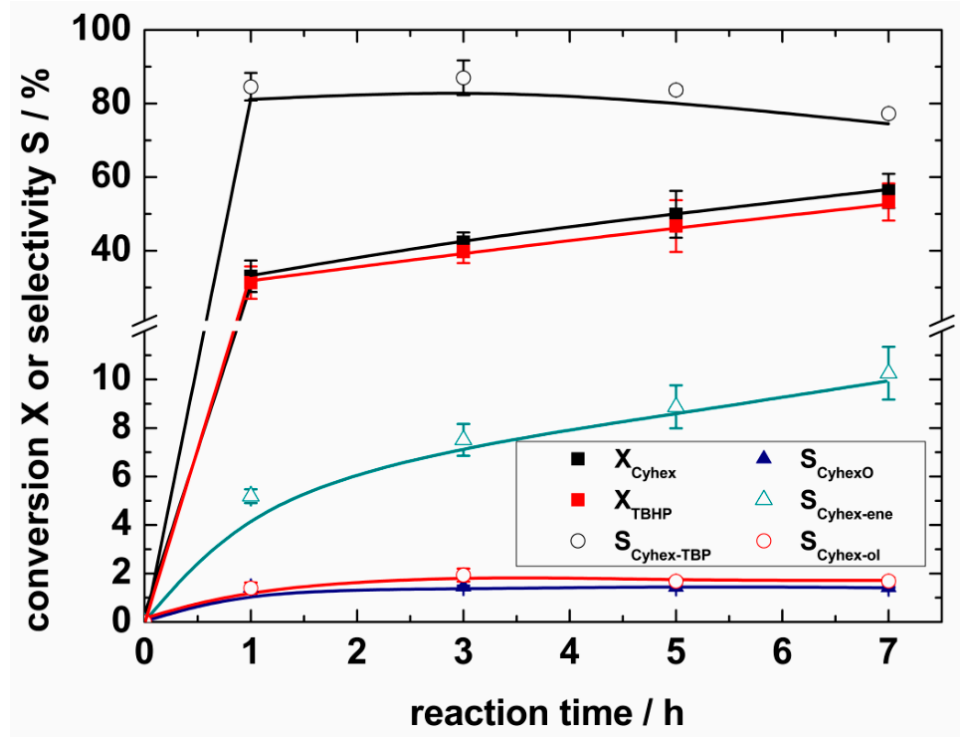

Figure 7. Conversion of cyclohexene $\mathrm{X}_{\mathrm{Cyhex}}$ and TBHP $\mathrm{X}_{\mathrm{TBHP}}$, as well as selectivity for 1-(tertbutylperoxy)-2-cyclohexene $\mathrm{S}_{\text {Cyhex-TBP, }}$ cyclohexene oxide $\mathrm{S}_{\text {CyhexO }}$, 2-cyclohexen-1-one $\mathrm{S}_{\text {Cyhex-ene, }}$ 2-cyclohexen-1-ol $S_{\text {Cyhex-ol }}$ for 5 as a function of reaction time in liquid chloroform (reaction conditions as in Table 5). 
Table 5. Cu content, as well as turnover frequency TOF in the conversion of cyclohexene with TBHP over 1-5 as catalysts after $7 \mathrm{~h}\left(\mathrm{~T}=323 \mathrm{~K}, \mathrm{~V}_{\text {chloroform }}=15 \mathrm{~cm}^{3}, \mathrm{c}_{\text {cyclohexene }}=0.86 \mathrm{~mol} \mathrm{~L}^{-1}, \mathrm{n}_{\text {Cyhex }} / \mathrm{n}_{\mathrm{TBHP}}\right.$ $\left.=1 / 2, \mathrm{n}_{\text {Cu,cat }}=0.46 \mathrm{mmol}\right)$.

\begin{tabular}{ccc}
\hline Catalyst & Cu Content $\mathbf{a} / \mathbf{w t} \mathbf{~}$ & TOF/ $\mathbf{h}^{\mathbf{- 1}}$ \\
\hline $\mathbf{1}$ & 21.9 & 2.8 \\
$\mathbf{2}$ & 21.2 & 3.1 \\
$\mathbf{3}$ & 22.5 & 2.6 \\
$\mathbf{4}$ & 21.9 & 3.0 \\
$\mathbf{5}$ & 18.7 & 4.4 \\
$\mathrm{Cu}_{3}(\mathrm{BTC})_{2}$ & 29.6 & 3.0 \\
$\mathrm{Cu}\left(\mathrm{NO}_{3}\right)_{2}$ & 28.7 & 3.9 \\
\hline
\end{tabular}

The remaining $10 \%$ of the product selectivity is assumed to correspond to the formation of 3-methylcyclohexene (3\%), which is formed through a side reaction of Cyhex with the solvent chloroform and the formation of higher molecular weight products $(1 \%)$, such as polyperoxides or oligomers of Cyhex, which cannot be detected via GC analysis. In addition, the strong adsorption of the oxygenated products at the $\mathrm{Cu}$ sites [67-69] adds to the remaining product selectivity $(3 \%)$. The still "missing" $3 \%$ selectivity is within the experimental accuracy of the catalytic experiments. A similar product distribution was also observed for the other $\mathrm{Cu}$-containing MOFs 1-4, as well as for the reference catalysts $\mathrm{Cu}_{3}(\mathrm{BTC})_{2}$ and $\mathrm{Cu}\left(\mathrm{NO}_{3}\right)_{2}$ (conversion of Cyhex and TBHP and selectivity for Cyhex-TBP, CyhexO, Cyhex-ene, Cyhex-ol for 1-5, as well as $\mathrm{Cu}\left(\mathrm{NO}_{3}\right)_{2}$ and $\mathrm{Cu}_{3}(\mathrm{BTC})_{2}$ are shown in ESI, Figure S11). However, in contrast to 5, the selectivities for Cyhex-TBP found for 1-4 and $\mathrm{Cu}_{3}(\mathrm{BTC})_{2}$ are nearly the same and essentially independent of the cyclohexene conversion (Figure S12). Hence, assuming that the same reaction mechanism is valid for all the investigated solid catalysts, $\mathbf{5}$ probably exhibits a higher activity. This is confirmed by comparison of the TOFs obtained over 1-5 summarized in Table 5. While a similar activity (within experimental accuracy) over 1-4 compared to $\mathrm{Cu}_{3}(\mathrm{BTC})_{2}$ is observed, an up to 1.5-fold higher activity is reached in the presence of 5. Interestingly, the highest catalytic activity is observed for the MOF with the highest steric demand of the triazole substituents. However, among the studied catalysts, $\mathbf{5}$ has the lowest specific pore volume and specific surface area, as well as a relatively narrow maximum pore size of $540 \mathrm{pm}$ (cf. Table 4 and Figure 2; $\mathrm{Cu}_{3}(\mathrm{BTC})_{2}$ : pore size $\left.=1.6 / 1.1,0.6 \mathrm{~nm}[70,71] ; \mathrm{V}_{\text {micro }}=0.62 \mathrm{~cm}^{3} \mathrm{~g}^{-1}, \mathrm{~S}_{\mathrm{BET}}=1526 \mathrm{~m}^{2} \mathrm{~g}^{-1}\right)$. Hence, no clear connection between the textural properties of the studied triazolyl-based MOFs and the catalytic activity becomes obvious at first sight. In fact, different aspects probably contribute to the higher activity of 5 . According to the kinetic diameter of cyclohexene (0.6 nm [72]), which exceeds the maximum pore size of $\mathbf{5}(540 \mathrm{pm})$ the reaction could take place at the outer surface of $\mathbf{5}$. Nevertheless, 5 shows a similar activity to the $\mathrm{Cu}^{2+}$ ions from the dissolved $\mathrm{Cu}\left(\mathrm{NO}_{3}\right)_{2}$, and both catalysts were added with the same molar amount of $\mathrm{Cu}$ to the reaction solution; the selective oxidation of cyclohexene with TBHP likely takes place within the pores of $\mathbf{5}$. In the case of $\mathbf{1 - 4}$, the oxidation probably occurs mainly at the outer surface of the catalysts as they exhibit a lower activity than $\mathrm{Cu}\left(\mathrm{NO}_{3}\right)_{2}$, suggesting that only a part of the active sites are accessible for the reactants. Secondly, $\mathbf{5}$ has the most narrow maximum pore size (Figure 2), which could cause diffusion limitations within the pores, resulting in elongated contact times of the reactant on the active sites. In addition, while the specific surface area of $\mathbf{5}$ is approximately one half of the surface areas of $\mathbf{3}$ and $\mathbf{4}$, no significant difference of the specific pore volume can be observed in 4 and 5 (Table 4 ). Hence, 5 exhibits a relatively higher surface area within the pores, also contributing to the higher catalytic activity. At last, due to the different triazole substituents, the intrinsic activity of the $\mathrm{Cu}$ sites is probably also different, resulting in different Lewis acidity and, thus, catalytic properties for $\mathbf{1 - 5}$.

Overall, although linker functionalization with alkyl groups can significantly improve the hydrothermal stability and adsorption properties of the isomorphous series of MOFs, a fine-tuning of their catalytic activity merely based on the difference in steric demand is not evident. 
Nevertheless, the catalytic activity of $\mathbf{1 - 5}$ is within the range of results for the cyclohexene conversion with TBHP and Cyhex-TBP as the main reaction product as reported in the literature (Table 6). However, it has to be noted that, in contrast to $\mathbf{1 - 4}$, cyclohexene is able to access the pores of MFU-1 [73] and [Co $\left.{ }^{\mathrm{II}}(\mathrm{BPD})\right] \cdot 3 \mathrm{DMF}$ [74] (Table 6) (pore width of $1.8 \mathrm{~nm}$ for MFU-1 [73] and $1.1 \mathrm{~nm}$, as well as 4.5-7.0 nm respectively for [Co $\left.{ }^{\mathrm{II}}(\mathrm{BPD})\right] \cdot 3 \mathrm{DMF}$ [74]). Hence, MFU-1 and [Co $\left.{ }^{\mathrm{II}}(\mathrm{BPD})\right] \cdot 3 \mathrm{DMF}$ show a superior catalytic activity compared to $\mathbf{1 - 4}$ as the higher molar amount of active sites within 1-4 (0.46 mmol vs. $0.095 \mathrm{mmol} / 0.056 \mathrm{mmol}$ respectively) is not fully accessible for all reactants. In addition, other $\mathrm{Cu}$-containing MOFs show an overall higher selectivity for Cyhex-ene [42,44] and CyhexO $[39,40]$ with TBHP or molecular oxygen as the oxidant. As can be further seen from Table 6, $\left[\mathrm{Cu}_{2} \mathrm{~L}_{2}\right]$ ( $\mathrm{L}=$ bis(carboxyphenyl)-1,2,4-triazole) [50] even shows an up to 1.5-fold higher activity in comparison to 5 at the same reaction conditions, although both reactions could occur on the outer surface of the catalysts. This could be again caused by the different coordination environment of the catalytically active sites resulting in different intrinsic activity of the $\mathrm{Cu}$ sites and, thus, different Lewis acidity. In addition, low coordinated $\mathrm{Cu}$ sites at the outer surface of $\left[\mathrm{Cu}_{2} \mathrm{~L}_{2}\right]$ probably cause the higher activity compared to $\mathbf{1 - 5}$, as these active sites are easily accessible. Furthermore, Kobalz et al. [50] concluded that the conversion of cyclohexene probably occurs at the outer surface of $\left[\mathrm{Cu}_{2} \mathrm{~L}_{2}\right]$. The previous comparison of the catalytic results of $\mathbf{1}-\mathbf{5}$ to already published results (cf. Table 6) emphasizes that for the development of highly active and selective MOF-based catalysts, not only the steric demand of the linker substituents, but also the resulting pore structure, as well as the design of the coordinative and electronic environment of the active sites need to be carefully considered.

The crystal structure remains intact for 2,4 and 5 during the catalytic experiment. In contrast to $\mathrm{Cu}_{3}(\mathrm{BTC})_{2}$, no changes in reflection intensity or width are observed for the PXRD patterns of 2, 4 and 5 (Figures $\mathrm{S} 1$ and $\mathrm{S} 2$ ). In the case of $\mathrm{Cu}_{3}(\mathrm{BTC})_{2}$, the reflection intensity decreases probably due to remaining solvent molecules or adsorbed reactants or products from the conversion (Figure S3). However, a broadening of the reflections occurs for $\mathbf{1}$ and $\mathbf{3}$ (Figure S1). Even after resolvation with methanol, the PXRD patterns of $\mathbf{1}$ and $\mathbf{3}$ do not resemble the ones of the as-synthesized materials, indicating changes in the crystal structure during the catalytic conversion. These changes could also be a reason for the lowest catalytic activity of $\mathbf{1}$ and $\mathbf{3}$ within the investigated MOFs.

In another experiment, the heterogeneous nature of the catalytic conversion was proven by hot filtration of 5 and 3 (Figure S13). In contrast to 3, for $\mathbf{5}$, a further, but less pronounced progress of conversion was observed after filtration of the catalyst (after $3 \mathrm{~h}$ ) until $5 \mathrm{~h}$ of reaction due to the action of radicals. These are generated on the catalyst surface during the first $3 \mathrm{~h}$ of the experiment. After $5 \mathrm{~h}$ of reaction, the conversion lies within the range of the reaction without any added catalyst (Figure S13). After hot filtration, no copper for the reaction over 5 and $0.2 \mathrm{wt} \%$ of the copper in 3 was detected via elemental analysis by optical emission spectrometry with inductively coupled plasma (ICP-OES). However, the small amount of $0.05 \mathrm{mg}(0.2 \mathrm{wt} \%) \mathrm{Cu}$, which leached from 3 , was not able to further catalyze the conversion of cyclohexene with TBHP. Importantly, like $\mathrm{Cu}_{3}(\mathrm{BTC})_{2}, 3$ and 5 could be regenerated by Soxhlet extraction. A second activation in vacuum at $323 \mathrm{~K}$ and reuse in another catalytic run revealed no loss of activity and selectivity within the experimental accuracy (Figure S14). Therefore, the pore system of $\mathbf{3}$ and $\mathbf{5}$ regenerated after the catalytic conversion is still accessible, as can be seen from the $\mathrm{CO}_{2}$ isotherms (Figure S15). The previously mentioned results confirm the stability of the investigated catalysts and the heterogeneous nature of the reaction. 
Table 6. Cyclohexene conversion $\mathrm{X}_{\mathrm{Cyhex}}$, selectivity for 1-(tert-butylperoxy)-2-cyclohexene $\mathrm{S}_{\mathrm{Cyhex} \text {-TBP }}$ as the main reaction product over MOFs investigated for the selective oxidation of cyclohexene with TBHP.

\begin{tabular}{cccccc}
\hline Catalyst & $\mathbf{t} / \mathbf{h}$ & $\mathbf{X}_{\text {Cyhex }} / \%$ & $\mathbf{S}_{\text {Cyhex-TBP }} / \%$ & TOF/h $^{-1}$ & Reference \\
\hline $\mathbf{5}$ & 7 & 56 & 77 & 4.4 & this work \\
MFU-1 $^{\text {a }}$ & 11 & 25 & 64 & 3.8 & {$[73]$} \\
{$\left[\mathrm{CO}^{\mathrm{II}}(\mathrm{BPD})\right]^{3} \mathrm{DMF}^{\mathrm{b}}$} & 12 & 62 & 83 & 3.7 & {$[74]$} \\
{$\left[\mathrm{Cu}_{2} \mathrm{~L}_{2}\right]^{\mathrm{c}}$} & 7 & 82 & 56 & 6.6 & {$[50]$} \\
\hline
\end{tabular}

${ }^{a}$ Reaction conditions: cyclohexene ( $\left.16 \mathrm{mmol}\right)$, TBHP ( $\left.8 \mathrm{mmol}\right), 1,2,4$-trichlorobenzene ( $2 \mathrm{mmol}$; as internal standard), MFU-1 (0.095 mmol based on Co), no solvent, $343 \mathrm{~K} ;{ }^{\mathrm{b}}$ Reaction conditions: cyclohexene (4 mmol), TBHP (12 mmol), 1,2,4-trichlorobenzene (4 mmol; as the internal standard), $\mathrm{CH}_{2} \mathrm{Cl}_{2}\left(5 \mathrm{~cm}^{3}\right)$, [Co $\left.{ }^{\mathrm{II}}(\mathrm{BPD})\right] \cdot 3 \mathrm{DMF}(0.056 \mathrm{mmol}$ based on $\mathrm{Co})$, no solvent, $353 \mathrm{~K}^{\text {; }}{ }^{\mathrm{C}}$ Reaction conditions: cyclohexene $(25 \mathrm{mmol})$, TBHP in decane $(50 \mathrm{mmol})$, chlorobenzene (25 mmol; as internal standard), $\mathrm{CHCl}_{3}(15 \mathrm{~mL}),\left[\mathrm{Cu}_{2} \mathrm{~L}_{2}\right]$ ( $\mathrm{L}=$ bis(carboxyphenyl)-1,2,4-triazole, $0.46 \mathrm{mmol}$ based on $\mathrm{Cu}), 323 \mathrm{~K})$.

\section{Materials and Methods}

\subsection{Synthesis of ${ }_{\infty}^{3}\left[\mathrm{Cu}_{4}\left(\mu_{3}-\mathrm{OH}\right)_{2}\left(R^{1}-R^{2} \text {-trz-ia }\right)_{3}\left(\mathrm{H}_{2} \mathrm{O}\right)_{x}\right]\left(R^{1}=H, M e, E t ; R^{2}=M e, E t ; x=1,2 ; 1-5\right)$}

All reagents and solvents were purchased from commercial sources and used without further purification to synthesize the protonated ligands, as well as metal-organic frameworks. The protonated ligands were synthesized analogously to published procedures [45,47,48]. For solvothermal synthesis of 3, 4 and 5, steel autoclaves with appropriate polytetrafluoroethene inserts were used. Additionally, 1-5 are accessible as microcrystalline powders by refluxing equimolar amounts of $\mathrm{Cu}(\mathrm{OAc})_{2} \cdot \mathrm{H}_{2} \mathrm{O}(98 \%$, Sigma-Aldrich, Taufkirchen, Germany) or $\mathrm{CuSO}_{4} \cdot 5 \mathrm{H}_{2} \mathrm{O}(98 \%$, Sigma-Aldrich) and the appropriate ligand in $\mathrm{H}_{2} \mathrm{O}$ or a $\mathrm{H}_{2} \mathrm{O} / \mathrm{MeOH}\left(99.8 \%\right.$, AnalaR NORMAPUR ${ }^{\circledR}$ ACS, VWR, Darmstadt, Germany) or $\mathrm{H}_{2} \mathrm{O} / \mathrm{MeCN}\left(99.9 \%\right.$, CHROMASOLV ${ }^{\mathrm{TM}}$, VWR, Darmstadt, Germany) mixture $(1: 1, v / v)$. Solvent exchange of the as-synthesized samples was carried out via subsequent Soxhlet extraction with methanol (99.8\%, AnalaR NORMAPUR ${ }^{\circledR}$ ACS, VWR, Darmstadt, Germany). Detailed synthesis procedures and analytical data (PXRD, TD-PXRD, TG-DTA-MS) are reported in the ESI.

$\mathrm{Cu}_{3}(\mathrm{BTC})_{2}$ purchased from Sigma-Aldrich and activated at $393 \mathrm{~K}$ for $16 \mathrm{~h}$ in ambient air, as well as the $\mathrm{Cu}^{2+}$ salt $\mathrm{Cu}\left(\mathrm{NO}_{3}\right)_{2}(99.5 \%$, Merck, Darmstadt, Germany) were included in the catalytic experiments.

\subsection{Characterization of $\mathbf{1}-\mathbf{5}$}

Single crystals of 3, 4 and 5 were fixed with Fomblin ${ }^{\circledR}$ oil in the center of a plastic loop and mounted on a STOE IPDS-2T image plate diffractometer (Mo-K $\mathrm{K}_{\alpha} \lambda=71.073 \mathrm{pm}$; Stoe \& Cie GmbH, Darmstadt, Germany). The data sets were processed by STOE X-Area (Stoe \& Cie GmbH, Darmstadt, Germany) [75]. Crystal structures were solved by direct methods and refined using SHELX-2014 [76]. Positions of the framework hydrogen atoms were calculated for geometrically idealized positions. Contributions from disordered solvent molecules were removed by the SQUEEZE routine of the program package PLATON (Utrecht University, Utrecht, Netherlands) [56]. For specification of disordered atoms, split-position models were used. Crystal structure data and the results of the structure refinements are summarized in the ESI (Table S2). The program DIAMOND $3.2 \mathrm{f}$ (Crystal Impact GbR, Brandenburg, Germany) was used to visualize the structures [77]. CCDC 1526752-1526754 contain the supplementary crystallographic data. These data can be obtained free of charge from the Cambridge Crystallographic Data Centre via www.ccdc.cam.ac.uk/data_request/cif.

Prior to each adsorption experiment, the Soxhlet-extracted samples were activated in vacuum at $323 \mathrm{~K}$ for $24 \mathrm{~h}$. Nitrogen adsorption experiments were performed at $77 \mathrm{~K}$ with the commercially available volumetric adsorption analyzer BELSORP-max (MicrotracBEL Corp., Paris, France). High-pressure $\mathrm{CO}_{2}$ adsorption isotherms were recorded on a magnetic suspension balance (Rubotherm $\mathrm{GmbH}$, Bochum, Germany) at $298 \mathrm{~K}$. Various pressure transducers (Newport Electronics $\mathrm{GmbH}$, Deckenpfronn, Germany) were used in the range of vacuum $(p<0.05 \mathrm{~Pa})$ up to $10 \mathrm{MPa}$. Each 
adsorption isotherm was taken at least twice to ensure the reproducibility of the data (within $\pm 5 \%$ of the reported values). The ESI (cf. Section 2.3) contains a detailed description of these experiments.

Detailed description of PXRD measurements [78], TG-DTA-MS analyses, as well as elemental analyses of 1-5 are reported in the ESI (cf. Sections 2.2 and 3.2).

\subsection{Catalytic Selective Oxidation of Cyclohexene}

The catalytic experiments were carried out as already described in a previous report [50]. Fifteen centimeters cubed of chloroform (99.8+\%, Alfa Aesar, Karlsruhe, Germany) were loaded into a batch reactor followed by the addition of cyclohexene $(2.054 \mathrm{~g}, 25 \mathrm{mmol}, 99 \%$, Sigma-Aldrich, Taufkirchen, Germany), tert-butyl-hydroperoxide (TBHP, $7.545 \mathrm{~g}$, $50 \mathrm{mmol}, 5.5 \mathrm{M}$ solution in $n$-decane, Sigma-Aldrich) and chlorobenzene (2.814 g, $25 \mathrm{mmol}, 99+\%$, Acros organics, Nidderau, Germany) as the internal analytical standard corresponding to a molar ratio of cyclohexene:TBHP:chloroform of 1:2:7. To start the reaction, the catalysts $\mathbf{1}-\mathbf{5}$ (activated at $323 \mathrm{~K}$ for $16 \mathrm{~h}$ under vacuum) or the reference catalyst $\mathrm{Cu}_{3}(\mathrm{BTC})_{2}$ (activated at $393 \mathrm{~K}$ for $16 \mathrm{~h}$ in ambient air) used in different quantities ( $\mathrm{Cu}$ content of $0.46 \mathrm{mmol}$ ) were added to the reaction solution.

For recycling experiments, the catalyst was removed from the reaction mixture by centrifugation after the first run, Soxhlet extracted with methanol (99.8\%, Merck, Darmstadt, Germany), reactivated as described above and, again, added to a fresh reactant solution. To investigate if leaching of the catalytic species occurs, the catalyst was removed from the reaction mixture by centrifugation at reaction temperature after $3 \mathrm{~h}$ (hot filtration). The remaining reactant solution was again subjected to the reaction conditions for four more hours.

Liquid samples $\left(0.3 \mathrm{~cm}^{3}\right)$ were taken from the reaction mixture at different time intervals. Aliquots of the samples $\left(0.1 \mathrm{~cm}^{3}\right)$ were diluted in $0.5 \mathrm{~cm}^{3}$ chloroform and analyzed by capillary gas chromatography (Shimadzu GC 2010 equipped with a flame ionization detector, Shimadzu, Duisburg, Gemany) using nitrogen as the carrier gas. Product separation was achieved on a capillary column (95\% dimethylpolysiloxane cross-linked with 5\% diphenylpolysiloxane, Restek RTX-5, 30-m length, $0.25-\mathrm{mm}$ inner diameter, $0.25-\mu \mathrm{m}$ film thickness). Reaction products were identified by co-injection of authentic samples and by GC-MS (GC Varian 3800, Agilent Technologies, Waldbronn, Germany). Data on the conversion of cyclohexene were reproducible within $\pm 5 \%$, of TBHP conversion within $\pm 5 \%$, selectivity for 1-(tert-butylperoxy)-2-cyclohexene within $\pm 6 \%$ and selectivity for 2-cyclohexen-1-one $\pm 1 \%$ (overall for 3 and 5). The turnover frequency TOF (in $\mathrm{h}^{-1}$ ) was calculated as the ratio of the amount of converted cyclohexene and of the amount of copper sites present in the catalyst and the reaction time in hours within a reproducibility of $\pm 0.4 \mathrm{~h}^{-1}$.

\section{Conclusions}

The triazolyl isophthalate MOFs $\mathbf{1}-\mathbf{5}$ represent a series of isomorphous MOFs; $\mathbf{3}-\mathbf{5}$ were obtained as single crystals. Due to the arrangement of the triazole substituents towards the cavities, both the porosity and the pore size can be adjusted by the choice of the alkyl substituent. 3-5 are microporous materials with pore sizes in the range of $300-580 \mathrm{pm}$ and specific pore volumes of $0.19-0.36 \mathrm{~cm}^{3} \mathrm{~g}^{-1}$. Similar specific pore volumes to the calculated ones were determined from $\mathrm{CO}_{2}$ adsorption isotherms. In contrast, $\mathrm{N}_{2}$ is not a suitable probe molecule to prove the impact of the steric demand of the triazole substituents on the accessible pore volume. 1-5 exhibit a thermal stability up to $230^{\circ} \mathrm{C}$. The framework stability is increased by a higher steric demand of the substituents. Additionally, 5 remains stable even after $16 \mathrm{~h}$ in boiling water.

A direct relation between the steric demand of the triazole substituents and the catalytic activity of 1-5 in the liquid phase selective oxidation of cyclohexene with TBHP is not apparent. Nevertheless, all five MOFs are catalytically active. 5 is the most active catalyst. It even shows a 1.5-fold higher activity compared to the reference catalyst $\mathrm{Cu}_{3}(\mathrm{BTC})_{2}$ although its triazole substituent has the highest steric demand. Although, the cyclohexene conversion could partly take place at the outer surface of $\mathbf{5}$, the pores appear to be accessible for the reactants. Moreover, the $\mathrm{Cu}$ sites in $\mathbf{5}$ are probably more 
active towards the promotion of a radical-based oxidation reaction than the $\mathrm{Cu}$ sites in $\mathrm{Cu}_{3}(\mathrm{BTC})_{2}$. The comparable activity of 5 to that of the dissolved $\mathrm{Cu}\left(\mathrm{NO}_{3}\right)_{2}$ was rationalized by the cyclohexene conversion taking place within the micropores of 5. Additionally, reusability and hot filtration measurements of $\mathbf{3}$ and $\mathbf{5}$ confirmed the stability of the investigated materials during oxidation catalysis. The crystal structure remains intact, and no significant pore blocking was observed after catalysis by $\mathrm{CO}_{2}$ adsorption analysis.

The systematic investigations of this study thus confirm that small changes within the MOF structure can cause distinct differences in their thermal, adsorptive and catalytic properties. Hence, the design of adsorbents with specific gas adsorption properties is possible. Furthermore, the high potential of $\mathrm{Cu}$-containing MOFs for the selective oxidation of organic substrates due to fine-tuning of the catalytic properties is illustrated. Besides the steric demands, the design of the coordinative and electronic environment of the active $\mathrm{Cu}$ sites within MOF-based catalysts needs to be carefully considered.

Supplementary Materials: Supplementary materials can be accessed at www.mdpi.com/1996-1944/10/4/338/s1. Figure S1: X-ray powder diffraction (PXRD) patterns of 1 (top left), 2 (top right) and 3 (bottom) after reflux synthesis and after various post-synthetic treatments, as well as simulation from single crystal data $\left(\lambda\left(\mathrm{Cu}-K_{\alpha 1}\right)\right.$ $=154.060 \mathrm{pm})$; Figure S2: X-ray powder diffraction (PXRD) patterns $\left(\lambda\left(\mathrm{Cu}-\mathrm{K}_{\alpha 1}\right)=154.060 \mathrm{pm}\right)$ of 4 (left) and 5 (right) after solvothermal and reflux synthesis, as well as after various post-synthetic treatments and simulation from single crystal data; Figure S3: PXRD patterns of $\mathrm{Cu}_{3}(\mathrm{BTC})_{2}$ after activation at $393 \mathrm{~K}$ in air (before the catalytic experiment) and after use in the catalytic conversion of cyclohexene with TBHP for $7 \mathrm{~h}$ (after the catalytic experiment; $\mathrm{T}=323 \mathrm{~K}, \mathrm{~V}_{\text {chloroform }}=15 \mathrm{~cm}^{3}, \mathrm{c}_{\text {cyclohexene }}=0.86 \mathrm{~mol} \mathrm{~L}^{-1}, \mathrm{n}_{\mathrm{CyO}} / \mathrm{n}_{\mathrm{TBHP}}=1 / 2, \mathrm{~m}_{\text {cat }}=100 \mathrm{mg}$ ); Figure S4: Temperature-dependent X-ray powder diffraction (TD-PXRD) patterns of 1-5 after Soxhlet extraction with methanol $\left(\lambda\left(\mathrm{Cu}-\mathrm{K}_{\alpha 1}\right)=154.060 \mathrm{pm}\right)$; Figure S5: Simultaneous thermal analysis (TG-DTA-MS) of 1 (top) and 2 (bottom). MS-signals of $\left(\mathrm{H}_{2} \mathrm{O}\right)^{+}(m / z=18)$ and $(\mathrm{MeO})^{+}(m / z=31)$, as well as $(\mathrm{MeCN})^{+}(m / z=41)$ and $\left(\mathrm{CO}_{2}\right)^{+}$ $(m / z=44)$ illustrate the evaporation of guest molecules and the decomposition of the framework, respectively; Figure S6: Simultaneous thermal analysis (TG-DTA-MS) of 3 (top) and 4 (bottom). MS-signals of $\left(\mathrm{H}_{2} \mathrm{O}\right)^{+}(\mathrm{m} / z$ $=18)$ and $(\mathrm{MeO})^{+}(m / z=31)$, as well as $(\mathrm{MeCN})^{+}(m / z=41)$ and $\left(\mathrm{CO}_{2}\right)^{+}(\mathrm{m} / z=44)$ illustrate the evaporation of guest molecules and the decomposition of the framework, respectively; Figure S7: Simultaneous thermal analysis (TG-DTA-MS) of 5 (top) and 3 after activation under vacuum (bottom) at $313 \mathrm{~K}$ for $24 \mathrm{~h}$. MS-signals of $\left(\mathrm{H}_{2} \mathrm{O}\right)^{+}(\mathrm{m} / z=18),(\mathrm{MeCN})^{+}(\mathrm{m} / z=41)$ and $\left(\mathrm{CO}_{2}\right)^{+}(\mathrm{m} / z=44)$ illustrate the decomposition of the framework; Figure S8: Decomposition temperatures of 1-5 determined by simultaneous thermal analysis (TG-DTA-MS) and temperature-dependent powder X-ray diffraction (TD-PXRD); Figure S9: $\mathrm{CO}_{2}$ adsorption isotherms (298 $\mathrm{K}$ ) of 1-5 (black symbols, first measurement; green symbols, second measurement); Figure S10: $\mathrm{N}_{2}$ adsorption isotherms $\left(77 \mathrm{~K}, \mathrm{p}_{0}=97.152 \mathrm{kPa}\right)$ of $\mathbf{1}-\mathbf{5}$. Closed symbols: adsorption, open symbols: desorption (lines are to guide the eyes); Figure S11: Conversion of cyclohexene $\mathrm{X}_{\mathrm{Cyhex}}$ and TBHP $\mathrm{X}_{\mathrm{TBHP}}$, as well as selectivity for 1-(tert-butylperoxy)-2-cyclohexene $\mathrm{S}_{\text {Cyhex-TBP, }}$ cyclohexene oxide $\mathrm{S}_{\text {CyhexO }}$, 2-cyclohexen-1-one $\mathrm{S}_{\text {Cyhex-ene }}$ 2-cyclohexen-1-ol $\mathrm{S}_{\text {Cyhex-ol }}$ for compounds 1-5, $\mathrm{Cu}_{3}(\mathrm{BTC})_{2}$ (Basolite C300, Sigma-Aldrich) and the homogeneously dissolved $\mathrm{Cu}\left(\mathrm{NO}_{3}\right)_{2}\left(99.5 \%\right.$, Merck) after a reaction time of $7 \mathrm{~h}\left(\mathrm{~T}=323 \mathrm{~K}, \mathrm{~V}_{\text {chloroform }}=15 \mathrm{~cm}^{3}, \mathrm{c}_{\text {cyclohexene }}=0.86\right.$ mol L ${ }^{-1}, \mathrm{n}_{\text {Cyhex }} / \mathrm{n}_{\mathrm{TBHP}}=1 / 2, \mathrm{n}_{\mathrm{Cu}, \text { cat }}=0.46 \mathrm{mmol}$ ); Figure S12: Selectivity for 1-(tert-butylperoxy)-2-cyclohexene $\mathrm{S}_{\text {Cyhex-TBP }}$ for compounds $\mathbf{1 - 5}$ and $\mathrm{Cu}_{3}(\mathrm{BTC})_{2}$ different catalysts as a function of cyclohexene conversion $\mathrm{X}_{\mathrm{Cyhex}}$ during $1-7 \mathrm{~h}$ of reaction time at $323 \mathrm{~K}$ in liquid chloroform (reaction conditions as in Figure S11); Figure S13: Conversion of cyclohexene $X_{C y h e x}$ as a function of reaction time over $\mathbf{5}$ (left) and over $\mathbf{3}$ (right) and after removal of the catalyst by hot filtration after $3 \mathrm{~h}$ of reaction (reaction conditions as in Figure S11). In both diagrams, the conversion in the absence of a catalyst is also included; Figure S14: Conversion of cyclohexene $\mathrm{X}_{\mathrm{Cyhex}}$ and TBHP $\mathrm{X}_{\mathrm{TBHP}}$, as well as selectivity for 1-(tert-butylperoxy)-2-cyclohexene $\mathrm{S}_{\mathrm{Cyhex}-\mathrm{TBP}}$, cyclohexene oxide $\mathrm{S}_{\mathrm{CyhexO}}$, 2-cyclohexen-1-one $\mathrm{S}_{\text {Cyhex-ene, }}$ 2-cyclohexen-1-ol $\mathrm{S}_{\text {Cyhex-ol }}$ over $\mathrm{Cu}$-containing MOF catalysts after a reaction time of $5 \mathrm{~h}$ (reaction conditions as in Figure S11) before (run 1) and after separation and regeneration (run 2) of the catalyst (under vacuum at $323 \mathrm{~K}$ for $16 \mathrm{~h}$ for 5 and 3 and in air at $393 \mathrm{~K}$ for $16 \mathrm{~h}$ for $\mathrm{Cu}_{3}(\mathrm{BTC})_{2}$ ); Figure S15: $\mathrm{CO}_{2}$ adsorption isotherms ( $298 \mathrm{~K}$ ) of $\mathbf{3}$ and $\mathbf{5}$ before and after catalytic experiments (lines are to guide the eyes); Table S1: Synthesis method, ligand, metal salt, solvent, product and product yield for Compounds 1-5; Table S2: Single crystal structure data of compounds 3-5.

Acknowledgments: Financial support of the present work by the Deutsche Forschungsgemeinschaft (Schwerpunktprogramm (SPP) 1362, "Porous Metal-Organic Frameworks" and within the program of Open Access Publishing), the Universität Leipzig (within the program of Open Access Publishing), the Leipzig Graduate School of Natural Sciences "Building with Molecules and Nanoobjects (BuildMoNa)" and Research Academy Leipzig is gratefully acknowledged. Thanks are also due to Gerd Kommichau for providing XRD data, as well as to Kerstin Thiele and Heike Rudzik for elemental analysis.

Author Contributions: Ulrike Junghans and Merten Kobalz conceived and designed the experiments. Merten Kobalz performed the MOF synthesis, the determination of the MOF crystal structures, the PXRD 
measurements, the TG-DTA-MS analysis, as well as the adsorption experiments. Oliver Erhart assisted with the MOF synthesis. Hannes Preißler assisted with the adsorption experiments. Jörg Lincke synthesized MOF 3 and solved its crystal structure. Ulrike Junghans performed the catalytic experiments. Ulrike Junghans, Merten Kobalz, Jörg Lincke and Jens Möllmer analyzed the data. Ulrike Junghans and Merten Kobalz wrote and revised the paper. Harald Krautscheid and Roger Gläser revised the paper and supervised the project.

Conflicts of Interest: The authors declare no conflict of interest. The funding sponsors had no role in the design of the study. They further had no role in the collection, analyses or interpretation of data, nor in the writing of the manuscript, nor in the decision to publish the results.

\section{References}

1. Murray, L.J.; Dinca, M.; Long, J.R. Hydrogen storage in metal-organic frameworks. Chem. Soc. Rev. 2009, 38, 1294-1314. [CrossRef] [PubMed]

2. Rosi, N.L.; Eckert, J.; Eddaoudi, M.; Vodak, D.T.; Kim, J.; O’Keeffe, M.; Yaghi, O.M. Hydrogen Storage in Microporous Metal-Organic Frameworks. Science 2003, 300, 1127-1130. [CrossRef] [PubMed]

3. Wang, Q.; Bai, J.; Lu, Z.; Pan, Y.; You, X. Finely tuning MOFs towards high-performance post-combustion $\mathrm{CO}_{2}$ capture materials. Chem. Commun. 2016, 52, 443-452. [CrossRef] [PubMed]

4. Lässig, D.; Lincke, J.; Moellmer, J.; Reichenbach, C.; Moeller, A.; Gläser, R.; Kalies, G.; Cychosz, K.A.; Thommes, M.; Staudt, R.; et al. A Microporous Copper Metal-Organic Framework with High $\mathrm{H}_{2}$ and $\mathrm{CO}_{2}$ Adsorption Capacity at Ambient Pressure. Angew. Chem. Int. Ed. 2011, 50, 10344-10348. [CrossRef] [PubMed]

5. Van de Voorde, B.; Bueken, B.; Denayer, J.; de Vos, D. Adsorptive separation on metal-organic frameworks in the liquid phase. Chem. Soc. Rev. 2014, 43, 5766-5788. [CrossRef] [PubMed]

6. Bourrelly, S.; Llewellyn, P.L.; Serre, C.; Millange, F.; Loiseau, T.; Ferey, G. Different adsorption behaviors of methane and carbon dioxide in the isotypic nanoporous metal terephthalates MIL-53 and MIL-47. J. Am. Chem. Soc. 2005, 127, 13519-13521. [CrossRef] [PubMed]

7. Pan, L.; Parker, B.; Huang, X.; Olson, D.H.; Lee, J.; Li, J. Zn(tbip) (H2tbip = 5-tert-Butyl Isophthalic Acid): A Highly Stable Guest-Free Microporous Metal Organic Framework with Unique Gas Separation Capability. J. Am. Chem. Soc. 2006, 128, 4180-4181. [CrossRef] [PubMed]

8. Peng, Y.; Krungleviciute, V.; Eryazici, I.; Hupp, J.T.; Farha, O.K.; Yildirim, T. Methane storage in metal-organic frameworks: Current records, surprise findings, and challenges. J. Am. Chem. Soc. 2013, 135, 11887-11894. [CrossRef] [PubMed]

9. Barea, E.; Turra, F.; Navarro, J.A.R. Separation and Purification of Gases by MOFs. In Metal-Organic Frameworks: Application from Catalysis to Gas Storage; Farrusseng, D., Ed.; Wiley-VCH Verlag GmbH \& Co. KGaA: Weinheim, Germany, 2011; pp. 69-92.

10. Kreno, L.E.; Leong, K.; Farha, O.K.; Allendorf, M.; van Duyne, R.P.; Hupp, J.T. Metal-organic framework materials as chemical sensors. Chem. Rev. 2012, 112, 1105-1125. [CrossRef] [PubMed]

11. Horcajada, P.; Gref, R.; Baati, T.; Allan, P.K.; Maurin, G.; Couvreur, P.; Ferey, G.; Morris, R.E.; Serre, C. Metal-organic frameworks in biomedicine. Chem. Rev. 2012, 112, 1232-1268. [CrossRef] [PubMed]

12. Farrusseng, D.; Aguado, S.; Pinel, C. Metal-Organic Frameworks: Opportunities for Catalysis. Angew. Chem. Int. Ed. 2009, 48, 7502-7513. [CrossRef] [PubMed]

13. Chughtai, A.H.; Ahmad, N.; Younus, H.A.; Laypkov, A.; Verpoort, F. Metal-organic frameworks: Versatile heterogeneous catalysts for efficient catalytic organic transformations. Chem. Soc. Rev. 2015, 44, 6804-6849. [CrossRef] [PubMed]

14. Xamena, F.X.L.; Gascon, J.; Spivey, J. Metal Organic Frameworks as Heterogeneous Catalysts; The Royal Society of Chemistry: Cambridge, UK, 2013.

15. Gascon, J.; Corma, A.; Kapteijn, F.; Xamena, F.X.L. Metal Organic Framework Catalysis: Quo vadis? ACS Catal. 2014, 4, 361-378. [CrossRef]

16. Kitagawa, S.; Kitaura, R.; Noro, S.-I. Functional porous coordination polymers. Angew. Chem. Int. Ed. 2004, 43, 2334-2375. [CrossRef] [PubMed]

17. Guillerm, V.; Kim, D.; Eubank, J.F.; Luebke, R.; Liu, X.; Adil, K.; Lah, M.S.; Eddaoudi, M. A supermolecular building approach for the design and construction of metal-organic frameworks. Chem. Soc. Rev. 2014, 43, 6141-6172. [CrossRef] [PubMed] 
18. Henke, S.; Schneemann, A.; Wutscher, A.; Fischer, R.A. Directing the breathing behavior of pillared-layered metal-organic frameworks via a systematic library of functionalized linkers bearing flexible substituents. J. Am. Chem. Soc. 2012, 134, 9464-9474. [CrossRef] [PubMed]

19. Schwedler, I.; Henke, S.; Wharmby, M.T.; Bajpe, S.R.; Cheetham, A.K.; Fischer, R.A. Mixed-linker solid solutions of functionalized pillared-layer MOFs-adjusting structural flexibility, gas sorption, and thermal responsiveness. Dalton Trans. 2016, 45, 4230-4241. [CrossRef] [PubMed]

20. Colombo, V.; Montoro, C.; Maspero, A.; Palmisano, G.; Masciocchi, N.; Galli, S.; Barea, E.; Navarro, J.A.R. Tuning the adsorption properties of isoreticular pyrazolate-based metal-organic frameworks through ligand modification. J. Am. Chem. Soc. 2012, 134, 12830-12843. [CrossRef] [PubMed]

21. Handke, M.; Weber, H.; Lange, M.; Mollmer, J.; Lincke, J.; Gläser, R.; Staudt, R.; Krautscheid, H. Network flexibility: Control of gate opening in an isostructural series of Ag-MOFs by linker substitution. Inorg. Chem. 2014, 53, 7599-7607. [CrossRef] [PubMed]

22. Brozek, C.K.; Dinca, M. Cation exchange at the secondary building units of metal-organic frameworks. Chem. Soc. Rev. 2014, 43, 5456-5467. [CrossRef] [PubMed]

23. Cohen, S.M. Postsynthetic Methods for the Functionalization of Metal-Organic Frameworks. Chem. Rev. 2012, 112, 970-1000. [CrossRef] [PubMed]

24. Fei, H.; Shin, J.; Meng, Y.S.; Adelhardt, M.; Sutter, J.; Meyer, K.; Cohen, S.M. Reusable oxidation catalysis using metal-monocatecholato species in a robust metal-organic framework. J. Am. Chem. Soc. 2014, 136, 4965-4973. [CrossRef] [PubMed]

25. Dau, P.V.; Cohen, S.M. Modulating $\mathrm{H}_{2}$ sorption in metal-organic frameworks via ordered functional groups. Chem. Commun. 2014, 50, 12154-12157. [CrossRef] [PubMed]

26. Farrusseng, D.; Canivet, J.; Quadrelli, A. Design of functional metal-organic frameworks by post-synthetic modification. In Metal-Organic Frameworks: Application from Catalysis to Gas Storage; Farrusseng, D., Ed.; Wiley-VCH Verlag GmbH \& Co. KGaA: Weinheim, Germany, 2011; pp. $23-45$.

27. Deng, H.; Doonan, C.J.; Furukawa, H.; Ferreira, R.B.; Towne, J.; Knobler, C.B.; Wang, B.; Yaghi, O.M. Multiple functional groups of varying ratios in metal-organic frameworks. Science 2010, 327, 846-850. [CrossRef] [PubMed]

28. Taddei, M.; Costantino, F.; Ienco, A.; Comotti, A.; Dau, V.P.; Cohen, M.S. Synthesis, breathing, and gas sorption study of the first isoreticular mixed-linker phosphonate based metal-organic frameworks. Chem. Commun. 2013, 49, 1315-1317. [CrossRef] [PubMed]

29. Wee, L.H.; Alaerts, L.; Martens, J.A.; De Vos, D. Metal-organic frameworks as catalysts for organic reactions. In Metal-Organic Frameworks: Application from Catalysis to Gas Storage; Farrusseng, D., Ed.; Wiley-VCH Verlag GmbH \& Co. KGaA: Weinheim, Germany, 2011; pp. 195-208.

30. Nguyen, J.G.; Cohen, S.M. Moisture-resistant and superhydrophobic metal-organic frameworks obtained via postsynthetic modification. J. Am. Chem. Soc. 2010, 132, 4560-4561. [CrossRef] [PubMed]

31. Ma, D.; Li, Y.; Li, Z. Tuning the moisture stability of metal-organic frameworks by incorporating hydrophobic functional groups at different positions of ligands. Chem. Commun. 2011, 47, 7377-7379. [CrossRef] [PubMed]

32. Dhakshinamoorthy, A.; Alvaro, M.; Garcia, H. Metal-organic frameworks as heterogeneous catalysts for oxidation reactions. Catal. Sci. Technol. 2011, 1, 856-867. [CrossRef]

33. Luz, I.; Corma, A.; Llabres, I.; Xamena, F.X. Cu-MOFs as active, selective and reusable catalysts for oxidative $\mathrm{C}-\mathrm{O}$ bond coupling reactions by direct $\mathrm{C}-\mathrm{H}$ activation of formamides, aldehydes and ethers. Catal. Sci. Technol. 2014, 4, 1829-1836.

34. Dhakshinamoorthy, A.; Alvaro, M.; Garcia, H. Metal organic frameworks as efficient heterogeneous catalysts for the oxidation of benzylic compounds with t-butylhydroperoxide. J. Catal. 2009, 267, 1-4. [CrossRef]

35. Dhakshinamoorthy, A.; Alvaro, M.; Garcia, H. Aerobic Oxidation of Benzylic Alcohols Catalyzed by Metal-Organic Frameworks Assisted by TEMPO. ACS Catal. 2011, 1, 48-53. [CrossRef]

36. Junghans, U.; Suttkus, C.; Lincke, J.; Lässig, D.; Krautscheid, H.; Gläser, R. Selective oxidation of cyclooctene over copper-containing metal-organic frameworks. Microporous Mesoporous Mater. 2015, 216, 151-160. [CrossRef]

37. Jiang, D.; Mallat, T.M.; Meier, D.M.; Urakawa, A.; Baiker, A. Copper metal-organic framework: Structure and activity in the allylic oxidation of cyclohexene with molecular oxygen. J. Catal. 2010, 270, 26-33. [CrossRef]

38. Cancino, P.; Paredes-García, V.; Aguirre, P.; Spodine, E. A reusable CuII based metal-organic framework as a catalyst for the oxidation of olefins. Catal. Sci. Technol. 2014, 4, 2599-2607. [CrossRef] 
39. Aguirre, P.; Brown, K.; Venegas-Yazigi, D.; Paredes-García, V.; Spodine, E. [Cu(H2btec)(bipy)] $\infty$ : Reusable Metal Organic Polymer Catalyst for Epoxidation Reactions. Macromol. Symp. 2011, 304, 65-71. [CrossRef]

40. Brown, K.; Zolezzi, S.; Aguirre, P.; Venegas-Yazigi, D.; Paredes-Garcia, V.; Baggio, R.; Novak, M.A.; Spodine, E. $[\mathrm{Cu}(\mathrm{H}(2) \mathrm{btec})($ bipy) $]($ infinity): A novel metal organic framework (MOF) as heterogeneous catalyst for the oxidation of olefins. Dalton Trans. 2009, 1422-1427. [CrossRef]

41. Pramanik, A.; Abbina, S.; Das, G. Molecular, supramolecular structure and catalytic activity of transition metal complexes of phenoxy acetic acid derivatives. Polyhedron 2007, 26, 5225-5234. [CrossRef]

42. Fu, Y.; Sun, D.; Qin, M.; Huang, R.; Li, Z. Cu(ii)-and Co(ii)-containing metal-organic frameworks (MOFs) as catalysts for cyclohexene oxidation with oxygen under solvent-free conditions. RSC Adv. 2012, 2, 3309-3314. [CrossRef]

43. Cancino, P.; Paredes-García, V.; Aliaga, C.; Aguirre, P.; Aravena, D.; Spodine, E. Influence of the lanthanide(iii) ion in $\left\{\left[\mathrm{Cu}_{3} \mathrm{Ln}_{2}(\mathrm{oda})_{6}\left(\mathrm{H}_{2} \mathrm{O}\right)_{6}\right] \cdot \mathrm{nH}_{2} \mathrm{O}\right\} \mathrm{n}$ ( $\mathrm{Ln} \mathrm{III:} \mathrm{La}, \mathrm{Gd}, \mathrm{Yb}$ ) catalysts on the heterogeneous oxidation of olefins. Catal. Sci. Technol. 2017, 7, 231-242. [CrossRef]

44. Cancino, P.; Vega, A.; Santiago-Portillo, A.; Navalon, S.; Alvaro, M.; Aguirre, P.; Spodine, E.; García, H. A novel copper(II)-lanthanum(III ) metal organic framework as a selective catalyst for the aerobic oxidation of benzylic hydrocarbons and cycloalkenes. Catal. Sci. Technol. 2016, 6, 3727-3736. [CrossRef]

45. Lässig, D.; Lincke, J.; Krautscheid, H. Highly functionalised 3,4,5-trisubstituted 1,2,4-triazoles for future use as ligands in coordination polymers. Tetrahedron Lett. 2010, 51, 653-656. [CrossRef]

46. Bergmann, J.; Stein, K.; Kobalz, M.; Handke, M.; Lange, M.; Möllmer, J.; Heinke, F.; Oeckler, O.; Gläser, R.; Staudt, R.; et al. A series of isomorphous Metal-Organic Frameworks with rtl topology-Metal distribution and tunable sorption capacity via substitution of metal ions. Microporous Mesoporous Mater. 2015, 216, 56-63. [CrossRef]

47. Lincke, J.; Lässig, D.; Kobalz, M.; Bergmann, J.; Handke, M.; Möllmer, J.; Lange, M.; Roth, C.; Möller, A.; Staudt, R.; et al. An Isomorphous Series of Cubic, Copper-Based Triazolyl Isophthalate MOFs: Linker Substitution and Adsorption Properties. Inorg. Chem. 2012, 51, 7579-7586. [CrossRef] [PubMed]

48. Kobalz, M.; Lincke, J.; Kobalz, K.; Erhart, O.; Bergmann, J.; Lässig, D.; Lange, M.; Möllmer, J.; Gläser, R.; Staudt, R.; et al. Paddle Wheel Based Triazolyl Isophthalate MOFs: Impact of Linker Modification on Crystal Structure and Gas Sorption Properties. Inorg. Chem. 2016, 55, 3030-3039. [CrossRef] [PubMed]

49. Lincke, J.; Lässig, D.; Moellmer, J.; Reichenbach, C.; Puls, A.; Moeller, A.; Gläser, R.; Kalies, G.; Staudt, R.; Krautscheid, H. A novel copper-based MOF material: Synthesis, characterization and adsorption studies. Microporous Mesoporous Mater. 2011, 142, 62-69. [CrossRef]

50. Kobalz, K.; Kobalz, M.; Möllmer, J.; Junghans, U.; Lange, M.; Bergmann, J.; Dietrich, S.; Wecks, M.; Gläser, R.; Krautscheid, H. Bis(carboxyphenyl)-1,2,4-triazole Based Metal-Organic Frameworks: Impact of Metal Ion Substitution on Adsorption Performance. Inorg. Chem. 2016, 55, 6938-6948. [CrossRef] [PubMed]

51. Worch, C.; Kettner, F.; Lässig, D.; Lincke, J.; Krautscheid, H.; Gläser, R. Tuning the catalytic activity of the heteronuclear coordination polymers [CoxZn1-x(tdc)(bipy)] and $\left[\mathrm{Co}_{x} \mathrm{Zn}_{1-\mathrm{x}}\left(\mathrm{Me}_{2} \operatorname{trz}-p \mathrm{ba}\right)_{2}\right]$ in the epoxidation of cyclooctene via isomorphous substitution. Catal. Commun. 2014, 44, 46-49. [CrossRef]

52. Dhakshinamoorthy, A.; Asiri, A.M.; Garcia, H. Metal-Organic Frameworks as Catalysts for Oxidation Reactions. Chem. Eur. J. 2016, 22, 8012-8024. [CrossRef] [PubMed]

53. Dhakshinamoorthy, A.; Asiri, A.M.; Garcia, H. Mixed-metal or mixed-linker metal organic frameworks as heterogeneous catalysts. Catal. Sci. Technol. 2016, 6, 5238-5261. [CrossRef]

54. Leus, K.; Liu, Y.-Y.; van der Voort, P. Metal-Organic Frameworks as Selective or Chiral Oxidation Catalysts. Catal. Rev. Sci. Eng. 2014, 56, 1-56. [CrossRef]

55. Blatov, V.A.; Shevchenko, A.P.; Serezhkin, V.N. TOPOS 3.2: A new version of the program package for multipurpose crystal-chemical analysis. J. Appl. Crystallogr. 2000, 33, 1193. [CrossRef]

56. Spek, A.L. Single-crystal structure validation with the program PLATON. J. Appl. Crystallogr. 2003, 36, 7-13. [CrossRef]

57. Computing Pore Size Distribution-PSDsolv. Available online: http://supriyob.wordpress.com/about/ research/ (accessed on 21 August 2016).

58. Gelb, L.D.; Gubbins, K.E. Pore Size Distributions in Porous Glasses: A Computer Simulation Study. Langmuir 1999, 15, 305-308. [CrossRef]

59. Bhattacharya, S.; Gubbins, K.E. Fast method for computing pore size distributions of model materials. Langmuir 2006, 22, 7726-7731. [CrossRef] [PubMed] 
60. Horike, S.; Shimomura, S.; Kitagawa, S. Soft porous crystals. Nat. Chem. 2009, 1, 695-704. [CrossRef] [PubMed]

61. Kitagawa, S.; Kondo, M. Functional Micropore Chemistry of Crystalline Metal Complex-Assembled Compounds. Bull. Chem. Soc. Jpn. 1998, 71, 1739-1753. [CrossRef]

62. Sing, K.S.W. Reporting physisorption data for gas/solid systems with special reference to the determination of surface area and porosity (Recommendations 1984). Pure Appl. Chem. 1985, 57, 603-619. [CrossRef]

63. Thommes, M.; Kaneko, K.; Neimark, A.V.; Olivier, J.P.; Rodriguez-Reinoso, F.; Rouquerol, J.; Sing, K.S. Physisorption of gases, with special reference to the evaluation of surface area and pore size distribution (IUPAC Technical Report). Pure Appl. Chem. 2015, 87, 1051-1069. [CrossRef]

64. Gurvich, L. Physico-chemical attractive force. II. J. Phys. Chem. Soc. Russ 1915, 47, 805-827.

65. Lowell, S.; Shields, J.; Thomas, M.A.; Thommes, M. Characterization of Porous Solids and Powders: Surface Area, Pore Size and Density; Springer: Dordrecht, The Netherlands, 2010.

66. Tonigold, M.; Lu, Y.; Mavrandonakis, A.; Puls, A.; Staudt, R.; Möllmer, J.; Sauer, J.; Volkmer, D. Pyrazolate-based cobalt(II)-containing metal-organic frameworks in heterogeneous catalytic oxidation reactions: Elucidating the role of entatic states for biomimetic oxidation processes. Chem. Eur. J. 2011, 17, 8671-8695. [CrossRef] [PubMed]

67. Calero, S.; Gomez-Alvarez, P. Insights into the Adsorption of Water and Small Alcohols on the Open-Metal Sites of Cu-BTC via Molecular Simulation. J. Phys. Chem. C 2015, 119, 467-472. [CrossRef]

68. Harvey, S.D.; Eckberg, A.D.; Thallapally, P.K. Evaluation of copper-1,3,5-benzenetricarboxylate metal-organic framework (Cu-MOF) as a selective sorbent for Lewis-base analytes. J. Sep. Sci. 2011, 34, 2418-2426. [CrossRef] [PubMed]

69. Van Assche, T.R.C.; Duerinck, T.; Gutierrez Sevillano, J.J.; Calero, S.; Baron, G.V.; Denayer, J.F.M. High Adsorption Capacities and Two-Step Adsorption of Polar Adsorbates on Copper-Benzene-1,3,5-tricarboxylate Metal-Organic Framework. J. Phys. Chem. C 2013, 117, 18100-18111. [CrossRef]

70. Dhakshinamoorthy, A.; Alvaro, M.; Garcia, H. Commercial metal-organic frameworks as heterogeneous catalysts. Chem. Commun. 2012, 48, 11275-11288. [CrossRef] [PubMed]

71. Schlichte, K.; Kratzke, T.; Kaskel, S. Improved synthesis, thermal stability and catalytic properties of the metal-organic framework compound CU3(BTC)(2). Microporous Mesoporous Mater. 2004, 73, 81-88. [CrossRef]

72. Breck, D.W. Zeolite Molecular Sieves; Wiley-VCH Verlag GmbH \& Co. KGaA: New York, NY, USA, 1974.

73. Tonigold, M.; Lu, Y.; Bredenkötter, B.; Rieger, B.; Bahnmüller, S.; Hitzbleck, J.; Langstein, G.; Volkmer, D. Heterogeneous Catalytic Oxidation by MFU-1: A Cobalt(II)-Containing Metal-Organic Framework. Angew. Chem. Int. Ed. 2009, 48, 7546-7550. [CrossRef] [PubMed]

74. Lu, Y.; Tonigold, M.; Bredenkotter, B.; Volkmer, D.; Hitzbleck, J.; Langstein, G. A Cobalt(II)-containing Metal-Organic Framework Showing Catalytic Activity in Oxidation Reactions. Z. Anorg. Allg. Chem. 2008, 634, 2411-2417. [CrossRef]

75. Stoe \& Cie GmbH. X-Area; Stoe \& Cie GmbH: Darmstadt, Germany, 2006.

76. Sheldrick, G.M. A short history of SHELX. Acta Crystallogr. Sect. A: Found. Crystallogr. 2008, 64, $112-122$. [CrossRef] [PubMed]

77. Brandenburg, K. Diamond 3.2f; Crystal Impact GbR: Bonn, Germany, 2010.

78. Stoe \& Cie GmbH. WinXPow 3.0.2.7; Stoe \& Cie GmbH: Darmstadt, Germany, 2012.

(C) 2017 by the authors. Licensee MDPI, Basel, Switzerland. This article is an open access article distributed under the terms and conditions of the Creative Commons Attribution (CC BY) license (http:/ / creativecommons.org/licenses/by/4.0/). 